\title{
UNITED STATES FOREIGN ASSISTANCE LEGISLATION, 1947-1948
}

\author{
DAVID M. CRAWFORD广
}

April 3, 1949 marked the first anniversary of the European Recovery Program, and as amendments to the Economic Cooperation Act of 1948 have recently been enacted by Congress, this is an appropriate time to examine the four foreign aid acts passed since World War II and ascertain the pattern of United States legislation for world relief and recovery. ${ }^{1}$

It is the plan of this article to examine the causes which led to the passage of each aid act, review provisions common to two or more of these acts, and discuss provisions peculiar to the Economic Cooperation Act of 1948 , as amended, since this latter Act will presumably serve as the basis for future economic assistance legislation. ${ }^{2}$

At the close of World War II, as the United States and other nations were adjusting their sights to peacetime objectives, it became increasingly apparent to the leaders of many nations that certain countries required immediate assistance if they and their people were to survive. ${ }^{3}$ The United Nations was the logical body to furnish the required

$\div$ Member of the New York Bar and Attorney Adviser in the General Counsel's Ofice, Economic Cooperation Administration. The views expressed in this article are those of the writer and are in no way intended to indicate the views of the Economic Cooperation Administration.

1. The assistance acts which will be discussed are in the order of their passage: 61 StaT. 103 (1947), 22 U.S.C.A. $\$ 1401$ (Supp. 1948) (cited hereinaiter as the Greel:Turkish Assistance Act); 61 Stat. 125 (1947), 22 U.S.C.A. \$1411 (Supp. 1948) (cited hereinafter as the Relief Resolution); 61 STat. 934 (1947), 22 U.S.C.A. \$1411 (Supp. 1948) (cited hereinafter as the Interim Aid Act) ; 62 STAT. 137, 22 U.S.C.A. 1501 (1943) (cited hereinafter as the Foreign Assistance Act) ; Pub. L. No. 47, 81st Cong. 1st Sess. (April 19, 1949) (cited hereinafter as 1949 Amendments to the Economic Cooperation Act).

2. The Foreign Assistance Act embraced four titles: title I, "The Ecünomic $C_{0}$ operation Act of 1948" (cited hereinafter as the Economic Couperation Act); title II, the "International Children's Emergency Fund Assistance Act of 1948"; title III, the "Greek-Turkish Assistance Act of 1948"; and title IV, the "Chins Aid Act of 1048." The chief emphasis of this paper will center on the Economic Cooperation Act, as amended, since that Act contains the chief administrative and operational authority for the Foreign Assistance Act.

3. Countries such as Italy, France and Belgium were areas devastatcd by war, while others, such as Turkey, had experienced a constant drain on national income to maintain military forces at a level of constant readiness. See Statement of Dean Acheron before House Foreign Affairs Committee when he was Under-Secretary of State: "The Turkish Army has been mobilized since the beginning of World War II and this has put a severe strain upon the national economy.... [T] Jday, the Turlish ceonomy is no longer able to carry the full load required for its national defense and at the same time proceed with that economic development which is necessary to leep the country in a sound condition." H.R. REP. No. 314, EOth Cong., 1st Sess. 3 (1947). 
relief and the United Nations Relief and Rehabilitation Administration ${ }^{4}$ filled this important need until June, 1947. But UNRRA was short-lived and ceased to exist as an active distributor of relief at a time when the necessity for such aid was increasing. ${ }^{5}$

On March 12, 1947, shortly before the demise of UNRRA, President Truman delivered a message to Congress outlining the necessity for military and economic assistance to Greece and Turkey. In the course of his message, the President made the following observations in connection with the necessity for aiding Greece:

". . . The United States has received from the Greek Government an urgent appeal for financial and economic assistance. Preliminary reports from the American Economic Mission now in Greece and reports from the American Ambassador in Greece corroborate the statement of the Greek Government that assistance is imperative if Greece is to survive as a free nation." 6

In the same message, the President spoke of the problems confronting Turkey:

"Since the war Turkey has sought financial assistance from Great Britain and the United States for the purpose of effecting that modernization necessary for the maintenance of its national integrity. That integrity is essential to the preservation of order in the Middle East." 7

On May 22, 1947, Congress responded to the President's message with an Act to "Provide for Assistance to Greece and Turkey," 8 and the first of our post-war foreign assistance statutes became a reality. While the amount authorized to be appropriated, ${ }^{9} \$ 400,000,000$, was small in comparison to the $\$ 5,098,000,000$ involved in the Foreign Assistance Act, ${ }^{10}$ nevertheless a broad precedent of aid was estab-

4. Referred to hereinafter as UNRRA.

5. UNRRA was established in November, 1943, and ceased to exist June 30, 1947. Sen. Doc. No. 111, 80th Cong., 1st Sess. 1 (1947).

6. H.R. REp. No. 314, 80th Cong., 1st Sess. 4, 5 (1947).

7. Ibid.

8. See note 1 supra.

9. Greek-Turkish Assistance Act $\S 4$ (b). Section 4 (a) of that Act provided that until the appropriation was authorized the Reconstruction Finance Corporation was authorized and directed to make advances not to exceed $\$ 100,000,000$ which were to be repaid out of the appropriation when authorized. An appropriation of $\$ 400,000,000$ was aus thorized by Pub. L. No. 271, 80th Cong., 1st Sess. (July 30, 1947) (cited hereinafter as the Supplemental Appropriation Act of 1948).

10. Economic Cooperation Act $\$ 114$ (c) authorized appropriation of an amount not exceeding $\$ 4,300,000,000$; International Children's Emergency Fund $\$ 206$ authorizcd an appropriation of $\$ 60,000,000$; Greek-Turkish Assistance Act of $1948 \$ 302$ authorizcd an appropriation not to exceed $\$ 275,000,000$; China Aid Act $\$ 404$ (a) authorized an appropriation not to exceed $\$ 338,000,000$, while $\S 404$ (b) authorized an appropriation to the 
lished combining both economic and military assistance, the former including recovery projects as well as relief items. ${ }^{11}$

Although the Greek-Turkish Assistance Act was the first of the 1947-48 aid acts passed, the necessity for such legislation had been recognized earlier in 1947 when the President, on February 21, had sent a recommendation to the Congress for authorization of an appropriation of $\$ 350,000,000$ "to assist in completing the great task of bringing relief from the ravages of the war to the people of liberated countries." Within a fortnight after passage of the Greek-Turkish Assistance Act, Congress acted upon the President's earlier relief recommendation by passing a "Joint Resolution providing for relief assistance to the people of countries devastated by war." 12

Following President Truman's message and recommendations to Congress, but prior to the passage of any assistance legislation, Dean Acheson, then Under-Secretary of State, spoke before the Delta Council at Cleveland, Mississippi on May S, 1947 and outlined a five-point program implementing United States international, political and economic policies. Secretary Acheson's recommendations included: (1) an increase in American exports, (2) elimination of trade barriers, (3) the concentration of United States "emergency assistance in areas where it will be most effective in building world political and economic stability, in promoting human freedom and democratic institutions, in fostering liberal trading policies, and in strengthening the authority of the United Nations," (4) pushing ahead with the restoration of Germany and Japan, (5) the continuation of Congressional delegation to the executive branch of powers over the sale, transportation and exportation of commodities upon which our security depends. ${ }^{13}$

Thus for some months prior to June 5, 1947, when Secretary Marshall delivered his address at Harvard College Commencement, which served as the basis for the European Recovery Program, our Government had recognized and demonstrated that it would accept the responsibility of providing foreign assistance. But Secretary Marshall added a new and important ingredient to foreign aid, for his plan had as its keystone the concept of European nations acting in concert to work out their economic salvation. Secretary Marshall visualized this part of the program in his speech as follows:

\footnotetext{
"It would be neither fitting nor efficacious for this Government to undertake to draw up unilaterally a program designed to place
}

President of $\$ 125,000,000$. See SEN. REP. No. 1626, S0th Cong., 2d Sess. 16 (1948), for a breakdown of these authorized amounts.

11. Pub. L. No. 793, 80th Cong., 2d Sess. (June 28, 1948) (cited hereinafter as the Foreign Aid Appropriation Act of 1949), appropriated $\$ 4,000,000,000$ to carry out the provisions of title I of the Foreign Assistance Act of 1948.

12. See note 1 sitpra.

13. Sen. Doc. No. 111, 80th Cong., 1st Sess. 2 (1947). 
Europe on its feet economically. This is the business of the Europeans.

"The initiative, I think must come from Europe. The role of this country should consist of friendly aid in the drafting of a European program and of later support of such a program so far as it may be practical for us to do so. The program should be a joint one, agreed to by a number, if not all European nations." 14

The response of England and France to this proposal was enthusiastic and on June 13, 1947, Britain's Foreign Secretary Bevin hailed Marshall's statement as "a real attempt ... to (create) a healthy world," and on June 14, French Foreign Minister Georges Bidault invited Mr. Bevin to discuss the Marshall proposal. On June 17, talks opened in Paris; it was at once apparent that Soviet participation would be desirable and Molotov was invited to join the group. Molotov attended the initial meetings, but on July 2, 1947, denounced the plan and shortly thereafter Russia withdrew from the committee meetings which looked toward European recovery and subsequently so instructed its satellites. ${ }^{15}$

It was then that the full import of Russia's intention to take advantage of economic chaos to speed the spread of communism became increasingly clear, not only from its stand vis-à-vis the western powers in the United Nations, but also from the Soviet's attitude towards this and other basic problems confronting peace-seeking governments throughout the world. Now the necessity for European recovery became doubly important; essential for the preservation of the individuals requiring assistance and necessary for the security of all noncommunist governments. ${ }^{16}$

While the nations of Europe were reacting to Secretary Marshall's

14. Sen. Doc. No. 111, 80th Cong., 1st Sess. 2,3 (1947). S. 1209, 81st Cong., 1st Sess. $\$ 1$ (1949), provided for an amendment to the preamble of the Economic Cooperation Act $\S 102$ (a) by adding the words "to encourage the unification of Europe," and the 1949 Amendments to the Economic Cooperation Act amend $\S 102$ (a) to include this pronounccment of policy-SEn. REP. No. 100, 81st Cong., 1st Sess. 7 (1949).

15. Rumania, Bulgaria, Poland and Yugoslavia refused invitations to attend a meeting in Paris to discuss the Marshall Plan and on July 10, 1947, after Premier Clement Gottwald of Czechoslovakia had flown to Moscow for instruction, his Government declitted the invitation, with the announcement: "Acceptance of the invitation might be construcd as an action against the Soviet Union." On the same day, Hungary, Albania and Finland sent refusals. SEN. Doc. No. 111, 80th Cong., 1st Sess. 207 (1947).

16. On Oct. 6, 1947, Pravda announced the organization of the Cominform representing the Communists of nine nations, Russia, Yugoslavia, France, Italy, Poland, Bulgaria, Czechoslavakia, Hungary, and Rumania, with headquarters in Belgrade. The program of the Cominform, as set forth by Zhdanov on Oct. 22, 1947, called upon Communists everywhere to wreck the Marshall Plan as an instrument designed by the United States to achieve "World domination by American Imperialism." SEN. Doc. No. 111, 80th Cong., 1st Sess. 6 (1947). 
proposal, our own Government commenced studies of the impact of such a plan and the manner in which it could be worked out. On June 22, 1947 President Truman appointed a committee of specialists within the Government popularly known as the "Irug committee," 17 to study the state of the nation's resources in order to determine the United States' ability to support the Marshall plan. On October 19, 1947 the committee submitted its full report to the President. ${ }^{15}$ The second committee, which functioned on an ad hoc basis, was known as the Council of Economic Advisers, and was commissioned to study "the impact on our economy of aid to other countries." 10 This committee submitted its report to the President on October $28,1917.93$

The third, and perhaps best known, of these executive committees was the 19 member advisory committee under the chairmanship of the Secretary of Commerce, W. Averell Harriman. ${ }^{21}$ This committee consisted of financial, business and agricultural leaders and was charged with the responsibility of studying the broad aspects of the aid program and to advise the President "on the limits within which the United States may supply and wisely plan to extend such assistance." 22 After extensive study, the Harriman Committee submitted its report to the President on November 7, 1947. ${ }^{23}$

While the executive branch was preparing itself with facts and figures, the legislative branch commenced a study. On July 22, 1947, the House of Representatives decided to make its own inquiry and on July 29 a select committee under the Chairmanship of Representative Eaton was appointed to make a study of conditions in Europe. The committee, ${ }^{24}$ under its vice-chairman, Representative Herter, sailed

17. This committee was under the Chairmanship of Julius A. Krug, Secretary of the Interior.

18. National Resources and Foreign Aid (Dept. Interior 1947).

19. This committee was composed of Dr. Edwin G. Nourse, Chairman, Leon Keyserling and John D. Clark.

20. Councti of Econoaitc Advisors, The Inspact of Foreigat Aid uron tae DoSIESTIC ECONOMIY (1947).

21. Mir. Harriman is now the United States' Special Representative in Europe appointed in accordance with Foreign Assistance Act $\$ 108$.

22. Nembers of this committee included Mrr. Paul Hoffman, Administrator of ECA, Dr. Edwin G. Nourse, Leon Keyserling, Hiland Batcheller, Robert Earle Buchanan, W. Randolph Burgess, James B. Carey, Granville Conway, Melville F. Coolbaugh, Chester C. Davis, R. R. Deupree, Calvin B. Hoover, Robert Koenig, Edward S. Alason, George Meany, Harold G. Moulton, William L. Myers, Robert Gordon Sproul, Owen D. Young, Robert M. LaFollette, Jre, and John L. Collyer.

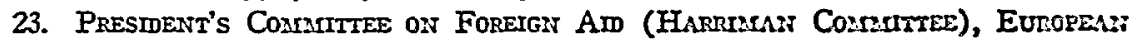
RECOVERY AND ANIERICAN AID (1947).

24. Members of this committee were: Reps. Charles A. Eaton, Christian A. Herter, Thomas A. Jenkins, Charles A. Wolverton, August H. Andresen, Francis Case, John C. Kunkel, John M. Vorys, Charles W. Vursell, W. Kingsland ALacy, Richard M. Ni:on, 
for Europe on August 28, 1947 and submitted its report to the committee as a whole on November $5,1947 .{ }^{25}$

During this period, progress was being made in Europe. On July 15, 1947, the Committee for European Economic Cooperation appointed working committees to prepare reports on the economic requirements of the member countries. Later in the summer, these committees reconvened in Paris to complete the CEEC report which was submitted to the Secretary of State on September 22, 1947.20 The prospective recipients of United States assistance had demonstrated by word and deed that they were ready to participate in a long-range recovery program which required mutual cooperation and maximum self-help.

However, while these preparations for a long-range recovery program were in progress on both sides of the Atlantic, the condition in several countries was becoming so critical that emergency aid had to be extended to them if they were to enjoy a full and active participation in the recovery program. On October 24, 1947, President Truman, in a radio message wherein he set forth his reasons for calling a special session of Congress, stated:

". . . [A] period of crisis is now at hand. The perils of hunger and cold in Europe make this winter a decisive time in history. All the progress of reconstruction and all the promise of future plans are endangered. If European nations are to continue their recovery, they must get through this winter without being crippled by economic paralysis and resulting chaos.

"In advance of our decision on the long-range European recovery plan, we must help some nations through this immediate crisis. The most imminent danger exists in France and in Italy. If the economies of these countries collapse and the people succumb to totalitarian pressures, there will be no opportunity for them or for us to look forward to their recovery so essential to world peace." ${ }^{27}$

The Special Session convened on November 17, 1947, and just one

E. E. Cox, James P. Richards, Francis E. Walter, Harold D. Cooley, George H. Mahon, Overton Brooks, Eugene J. Keogh and A. S. Mike Monroney.

25. This committee, popularly known as the Herter Committee, split up into teams of three and four which then covered various countries and reported on conditions in the area assigned. The final report, H.R. Rep. No. 1845, 80th Cong., 2d Sess. (1948), constitutes an excellent reference for the study of European recovery.

26. Compittee of European Economic Cooperation, Vol. I, General Report (Dept. State Pub. No. 2930, European Series No. 28) (1947) signed by the sixtecn nations participating in European Conference, presented to the United States. See SEN. Doc. No. 111, 80th Cong., 1st Sess. 191 (1947), for basic assumptions of CEEC report. In the light of the recent decline in prices, it is interesting to note an assumption of the CEEC report that prices for imports would be reduced in 1949 as compared with July, 1947 by $73 / 2 \%$, in 1950 by $10 \%$, and in 1951 by $121 / 2 \%$.

27. See Sen. Doc. No. 111, 80th Cong., 1st Sess. 65-72 (1947), for the background on the need for immediate aid to France, Austria and Italy. 
month later the Congress had passed the Interim Aid Act,"s authorizing an appropriation of not to exceed $\$ 597,000,000 .^{23}$ In less than seven months the United States had passed three acts authorizing assistance to foreign countries exceeding $\$ 1,300,000,000$. The stage had been well set for the passage of the "Foreign Assistance Act of 1918" in April of the following year.

Consequently, when the Eightieth Congress convened in January, 1948 , the voluminous reports compiled by the executive and legislative committees here and abroad were available for study along with the testimony of experts in foreign affairs who had been appearing before the Senate Foreign Relations and House Foreign Affairs Committees since December, 1947. In addition, the experience derived from the enactment of three assistance statutes within the closing months of the first session of the Eightieth Congress could be drawn upon in formulating a master plan for four-year foreign aid.

Provisions common to two or more of the assistance acts will be discussed in the following section, ${ }^{30}$ and the subsequent section will discuss provisions first incorporated in the Economic Cooperation Act.

\section{Provisions Conaron to Two or More of the Foreign Aid Acts Passed SINCE Wordd War II}

Each of the provisions discussed in this section is common to two or more of the four assistance acts of $1947-48 .{ }^{31}$ A capitulation of these basic provisions reveals the nature of the problems which Congress has faced in enacting foreign assistance legislation and the manner in which it has dealt with these problems.

Provisions in this category include agreements with recipient countries; methods of financing aid; deposits of local currency; restrictions on procurement; price control; assistance to voluntary, non-profit relief agencies; reparations; quarterly reports to Congress; and termination rights.

\section{Agreements between United States and Countries Receiving Aid}

A noticeable trend in the four assistance acts is the growing emphasis

28. See note 1 supra.

29. Interim Aid Act $\$ 11$. Pub. L. No. 393, 80th Cong., 1st Sess. (Dec. 23, 1947) (hereinafter cited as the Third Supplemental Appropriation Act of 1948), appropriated $\$ 522,000,000$ to carry out the provisions of the Interim Aid Act.

30. When comparing the aid acts, it should be borne in mind that the necessity for military as well as economic assistance governed the terms of the Greel-Turlish Assistance legislation and that there was a departure from the double standard of economic and military aid in the two subsequent acts which were limited to economic assistance. However, there was a limited endorsement of military assistance in titles III and IV of the Foreign Assistance Act.

31. See note 1 stipra. 
on agreements to be concluded with countries receiving aid. ${ }^{32}$ The first act, the Greek-Turkish Assistance Act of 1947, merely contained a requirement that, as a condition precedent to the receipt of assistance, the recipient government was to agree, inter alia, to give free access to United States government officials, not to transfer title to goods under the Act without the consent of the President, and not to use any proceeds of a loan to pay off indebtedness to another country. ${ }^{33}$ However, an agreement was entered into with the Greek Government on June 20,1947 looking towards implementation of the objectives set forth in the Act, ${ }^{34}$ and on July 12, a similar agreement was concluded with the Turkish Government. ${ }^{35}$

Only a few weeks later, the Relief Resolution of 1947 was passed containing a section which required that a recipient country give assurance satisfactory to the President that it would undertake certain requirements set forth in the Resolution. ${ }^{36}$ To make doubly certain that these assurances were obtained, the Act appropriating funds for this relief repeated the section requiring assurances, ${ }^{37}$ and acting in compliance with these legislative instructions, agreements were entered into with Austria, Italy, Greece and China which included the assurance that the assisted country would adhere to the conditions prescribed by Congress. ${ }^{38}$

In the Interim Aid Act, Congress for the first time included a requirement that an agreement be entered into with the countries re-

32. "The Committee has made every effort to guarantee the success of this venture in the light of its past experience with foreign aid programs. Therefore, in addition to the multilateral undertakings, special bilateral agreements will be concluded between the United States and each of the participating countries." SEN. REP. No. 935, 80th Cong." 1st Sess. 44 (1948). See also H.R. Rep. No. 1585, 80th Cong., 1st Sess. 24 (1948).

33. Greek-Turkish Assistance Act $\$ 3$.

34. See Sen. Doc. No. 111, 80th Cong., 1st Sess. 177 (1947) for text of the Agreement of June 20, 1947.

35. See 1st Report to Congress on Assistance to Greece and Turkey (Dept. State Pub. No. 2957, Near Eastern Series No. 11) (1947); Second Report (Dept. State Pub. No. 3035, Economic Cooperation Series No. 3) (1948); Tund REFout (Dept. State Pub. No. 3149, Economic Cooperation Series No. 9) (1948) ; Fourri Rerort (Dept. State Pub. No. 3278, Economic Cooperation Series No. 12) (1948); Fifru Rerout (Dept. State Pub. No. 3371, Economic Cooperation Series No. 13) (1948).

36. Relief Resolution $\$ 3$.

37. The Supplemental Appropriation Act of 1948, note 9 supra.

38. Agreements with Austria signed June 25, 1947; with Italy, July 4, 1947; with Greece, July 8, 1947; with China, Oct. 27, 1947. The recital of having given assurances is found in the "whereas" clause of each agreement. Text of the agreements with Austria, Italy, and Greece is contained in First Report to Congress on the United State's Foreign Retref Program (Dept. State Pub. No. 2985) 32-47 (1947). The text of the agreement with China is contained in the SECOND REPORT to Congress on tIIE UNITED States Foreign Relief Program (Dept. State Pub. No. 3101, Economic Cooperation Series No. 5) 56-62 (1948). 
ceiving aid. This legislation made explicit provision for conditions of the agreement. ${ }^{39}$ Agreements were subsequently concluded with France, Italy and Austria carrying out these legislative instructions. ${ }^{43}$

By the time the Foreign Assistance Act of 1948 was under consideration, it was apparent that Congress would attach much importance to the conclusion of agreements with countries receiving aid.

Since the agreements were to become effective without legislative ratification, Congress had to set forth in the basic Act the desired provisions with a considerable degree of specificity. Accordingly, it was decided to include a statutory list of subjects to be covered in the agreements, in order to minimize the chance that Congressional intent would be circumvented.

Although Congress had no chance to ratify the agreements, the legislative bodies of certain recipient countries were required by their laws to ratify the agreements entered into by the executive branch of their governments. ${ }^{41}$ It was apparent that the necessity for legislative approval would force a considerable delay in the conclusion of these agreements. ${ }^{42}$ The time factor was enhanced by the increased number of countries eligible to receive assistance and by the ever-growing complexity of the provisions which seemed necessary for the agreements.

Accordingly, provision was made for a three-month period for negotiation and conclusion of agreements with the participating nations; during the interim period between April 3, 1948 and July 3, 1948, aid was extended to the participating countries upon their signing letters of intent. ${ }^{43}$ Actually, most of the three months was consumed in

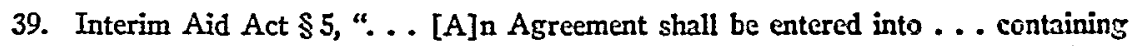
an undertaking by such country. . ." Ten undertakings were then listed. See Ser. REP. No. 771, 80th Cong., 1st Sess. 12 (1947):

"The committee attaches great importance to the proposed bilateral agreements which are to be concluded with the recipient countries, and which are similar to those already concluded with Italy, Austria, and Greece under the relief bill (Pub. L. \&4). These agreements respect the dignity of both parties and give assurance that the commodities furnished by the United States will be used to best advantage."

40. Art. II, $\$ 1$ of agreements concluded with France, Jan. 2, 1948; Austria, Jan. 3, 1948; Italy, Jan. 3, 1948. These agreements are set forth in Finst Reronr ro Co:acress on the United States Foreign Am Prograsr (Dept. State Pub. No. 3119, Ecomomic Cooperation Series No. 6) 25-32 (1948).

41. These countries were Belgium, Denmark, France, Greece, Ireland, Swcden and Turkey. The provisions to be included in the Economic Cooperation Agreements with the participating countries are set forth in the Economic Cooperation Act $\$ 115$ (b).

42. When testifying before the House Foreign Affairs Committce, Mr. Gross, Legal Advisor to the Secretary of State, testified that the three months' time vas includcd to give the countries an opportunity to consider the terms of these agreements. Sce Hcarings before the House Committee on Forcign Affairs on Unitcd Slates Forcign Poliey for a Post War World, pt. 1, 80th Cong., 2nd Sess. 54 (1948).

43. For the dates on which these letters of intent were signed, see Fmsr Reronr to Congress of the Econonic Cooperation Adxinnistration 67 (1948). 
negotiating the agreements. However, despite the fact that seven countries had not concluded bilateral agreements as of July 3, 1948, the flow of aid was temporarily interrupted to only four participating countries. ${ }^{44}$

All the agreements under the first three aid acts will be registered with the United Nations in accordance with section 102(a) of the United Nations Charter, and the State Department has already transmitted all of the agreements under the Economic Cooperation Act of 1948 for registration with the United Nations Secretariat in accordance with the terms of the Act. ${ }^{45}$

\section{Methods of Furnishing Financial Assistance}

Three methods have been utilized in the four assistance acts to make available dollar aid to the recipient countries. One arrangement, which has been employed in whole or in part in all the 1947-48 aid acts, is the extension of credit without requiring repayment. A second system is to extend credit on terms requiring repayment; this method was utilized to a limited extent in the Greek-Turkish Assistance Act and more fully in the Foreign Assistance Act.

The third method is the conditional payments plan and was devcloped in the fall of 1948 for use in furnishing assistance under the Economic Cooperation Act in accordance with the Agreement for IntraEuropean Payments and Compensations devised in October, 1948. This plan provides for the advance of grant funds by ECA to a participating country on condition that the country receiving the grant advance equivalent aid in their own currencies to other participating countries.

Many complex problems of international finance are implicit in determination of the methods to be used and the computation of the aliquot share of assistance to be furnished by each method.

The Senate Foreign Relations and House Foreign Affairs Committees recognized that full consideration should be given to the future financial position of each participating country to ascertain if it would be in a position to repay the amounts extended on credit terms. ${ }^{40}$ In

44. Aid was temporarily suspended to Belgium, France, British-U.S. Zones and French Zone of occupation in Germany. For a fuller analysis of the terms of the bilateral agreements, see Surrey, The Economic Cooperation Act of 1948, 36 CALIF. L. REv. 509, 513 (1948).

45. Foreign Assistance Act $\$ 121$ (c).

46. "The Committee has, however, established the criteria for determining whether assistance should be in the form of grants or loans. This determination is to depend primarily on two factors: (1) the character and purpose of the assistance, and (2) the capacity of the country concerned to make repayments without jeopardizing the accomplishment of the purposes of the bills." SEN. REP. No. 935, 80th Cong., 1st Sess. 48 (1948). See H.R. REP. No. 1585, 80th Cong., 1st Sess. 36 (1948) for House Committee vicws. 
general, the chances have not seemed good; obviously, the necessity for present aid has meant that most of the participating countries are in no position to be saddled with further debts. 77

Very little of the aid extended in the Greek program was on a repayment basis. ${ }^{43}$ The military aspects of an aid program can never be self-liquidating, the relief items could not reasonably be extended on terms of repayment and consequently, aid extended on credit terms was limited to certain capital goods reconstruction projects with repayment prospects. ${ }^{49}$ Similarly the necessity for the passage of the Relief Resolution and the Interim Aid Act precluded the possibility that any of the assistance rendered other countries under either act could be extended on a repayment basis. However, it should be noted that each of these assistance acts provided that aid could be extended on terms of repayment ${ }^{50}$ though no aid was extended on that basis.

When the European Recovery Program was in the formative stage, the terms upon which aid would be extended received careful consideration. Several basic problems had to be resolved. The first of these was how much of the entire amount of aid should be loan and how much grant. Congress decided that $\$ 1,000,000,000$ should be available for loans or guaranties; and that the appropriated funds could be loaned or granted. ${ }^{51}$ Secondly, it was necessary to determine the amount of loans and grants each country should receive and the terms

47. However, Iceland, Ireland, Sweden, and Turkey are all loan countrics. Belgium received a grant for the second calendar quarter of 1948 and since then has been all loan.

48. "The President may furnish assistance ... . upon terms and conditions determined by him (1) by rendering financial aid in the form of loans, credits, grants or othervise ..." Greek-Turkish Assistance Act $\$ 1$.

49. Military assistance to North Atlantic Pact countries participating in the Mrarshall Plan will have to be integrated and coordinated with economic assistance and with the European Recovery Program. Ernest A. Gross of the State Department, General Lyman A. Lemnitzer for the National Mfilitary Establishment and Alexander I. Henderson of ECA were appointed in January, 1949 to coordinate the presentation of military and economic assistance programs to Congress. Washington Post, Jan. 4, 1949, p. 1, col. 5.

50. Relief Resolution $\$ 2(a):$ “... [S]uch relief assistance shall be provided in the form of transfers of supplies, or the establishment in this country of credits . . . on such terms as the President may determine. ..."

Interim Aid Act \$3: "The President ... may, by allocation of funds ... to any" such existing departments, agencies, or independent establishments, or by establishing in this country credits subject to the control of the President. ..." See also id. $\$ 5$ (b) for undertaking by recipient country to make a commensurate deposit in local currency when any commodity is furnished on a basis of no repayment.

51. Foreign Assistance Act $\$ 111(\mathrm{c})(1)$. The Committee determined that at least one billion of the total 5.3 billion dollars should be available solely for loans and guaranties, and the bill so provides. The remaining 4.3 billion dollars which may be appropriated may be used either for grants or loans as the Administrator deems necessary, acting in consultation with the National Advisory Council on International MFonctary and Finameial Problems. H.R. Rep. No. 1585, SOth Cong., 2d Sess. 36 (194S). 
upon which the loans should be made. This determination was left up to the Administrator acting in consultation with the National Advisory Council on International Monetary and Financial Problems. ${ }^{62}$ After such consultation, the percentages of loans to grants were arrived at, and in the fall of 1948, the Administrator announced the percentage of loans and grants for each of the participating countries. ${ }^{53}$ The loans bear interest at the rate of $2 \mathrm{r} / 2 \%$; the term is 35 years; interest and principal are repayable semi-annually in equal installments; the first repayment of interest is not due until 1952, and the first repayment of principal is not due until 1956. ${ }^{54}$

During the first year of its operation, ECA loans totaled $\$ 973,000$,$000 .{ }^{55}$ These loans have not been extended solely on the basis of the dollars allocated in each country for specific projects which would be self-liquidating, but rather on the basis that the participating country would be able to repay the loan taking into consideration its present debt structure and schedule of repayments of principal and interest falling due for the next 35 years.

The Administrator and the Secretary of the Treasury testified before the Senate Committee on Foreign Relations that it would be unwise in the coming year to stipulate a fixed amount for loans as had been done last year since many of the participating countries were already heavily committed for the repayment of dollar loans and that stuch countries would need dollar-borrowing capacity to carry them after the end of the European Recovery Program. Consequently, neither the Senate nor the House committees' bills to amend the Economic Cooperation Act contained a limitation on the amount to be loaned or the amount to be granted, and no such limitation was incorporated in the amendments to the Economic Cooperation Act. ${ }^{56}$

Each aid act has contained a clause providing that certain funcls may be drawn down immediately from the Reconstruction Finance Corporation and then has provided that repayment shall be made

52. Hereinafter referred to as NAC. See p. 902 infra.

53. All cash countries were Portugal and Switzerland; all loan countries were Iceland, Ireland, Sweden and Turkey; loan-grant countries were Belgium, Luxembourg, Denmark, France, Italy, the Netherlands, Norway and the United Kingdom; and all grant countries were Austria, Greece, the French Zone of Germany, Bizone of Germany, and Trieste. SEN. REP. No. 13, 81st Cong., 1st Sess. 98 (1949).

54. Id. at 98-9, setting forth letter of Nov. 1, 1948, from Mr. Hoffman to Mr. Charles S. Dewey, Agent General, Joint Committee on Foreign Economic Cooperation, on the subject of loans and the manner in which the terms were decided.

55. See Sen. Rep. No. 100, 81st Cong., 1st Sess. 18 (1949), for a list of the amounts loaned the various countries.

56. S. 1209, 81st Cong., 1st Sess. $\$ 8$ (1949). SeN. Rep. No. 100, 81st Cong., 1st Sess. 17, 18 (1949). 1949 Amendments to the Economic Cooperation Act \& 8, amending \& 114 of the Economic Cooperation Act. 
from funds subsequently appropriated. ${ }^{57}$ This technique has been useful in making available funds for government departments and agencies which needed funds immediately, and a $\$ 750,000,000$ advance from the Reconstruction Finance Corporation for the period April 3, 1949 through June 30, 1949 was recommended by the Senate Foreign Relations Committee. A $\$ 1,000,000,000$ advance for the same period was recommended by the House Foreign Affairs Committee, and this amount was adopted in Conference and incorporated in the amendatory act. ${ }^{58}$

\section{Provision for Deposit of Counterpart Funds}

The concept of requiring countries receiving aid to deposit commensurate amounts of local currency in special accounts to match the dollar value of the assistance received had been first considered by the Senate Foreign Relations Committee when the terms of the Relief Resolution were being drafted and was subsequently adopted in that Resolution. ${ }^{59}$ When the Interim Aid Act was before the same committee, they endorsed what had been done under the Resolution, by incorporating a local currency deposit requirement in the Interim Aid Act. ${ }^{60}$ When considering the Economic Cooperation Act the House Foreign Affairs Committee stated that the benefits accruing from a wisely administered local currency fund would include: (a) reconstruction, expansion, and modernization of industrial capacity; (b) stabiliza-

57. Greek-Turkish Assistance Act $\$ 4(a)$. Not to exceed $\$ 100,000,000$ was authorized to be advanced by the Reconstruction Finance Corporation, 25\% of the amount authorized to be appropriated and 25\% of the $\$ 400,000,000$ actually appropriated by the Supplemental Appropriation Act of 1948 . The first section of the Relief Recolution authorized an advance from the Reconstruction Finance Corporation of not to exceed $\$ 75,000,000$. This was only $21 \%$ of the $\$ 350,000,000$ authorized to be appropriated, but was $22 \%$ of the $\$ 332,000,000$ actually appropriated by the Supplemental Appropriation Act of 1948. The Interim Aid Act $\$ 11$ (a) authorized to be appropriated an amount not to exceed $\$ 597,000,000$, and $\$ 11$ (d) authorized an advance from RFC not to exceed $\$ 150,000,000$ or $25 \%$. This was, however, almost $30 \%$ of the $\$ 522,000,000$ actually appropriated by the Third Supplemental Appropriation Act of 1948. The Economic Cooperation Act $\$ 114(\mathrm{c})$ authorized to be appropriated an amount not to excecd $\$ 4,300,000$,$000 ; \$ 114$ (a) authorized the RFC to advance an amount not to exceed $\$ 1,000,000,000$, which was $23 \%$ of the amount authorized and $25 \%$ of the $\$ 4,000,000,000$ actually appropriated by title I of the Foreign Aid Appropriation Act of 1949.

58. S. 1209, \$1st Cong., 1st Sess. $\$ 9$ (1949). H.R. 3748, S1st Cong., 1st Sess. $§ \&(b)$ (1949). 1949 Amendments to the Economic Cooperation Act. $\S 8(\mathrm{~b})$, amending $\$ 114$ of that Act.

59. Relief Resolution $\$ 6$.

60. Interim Aid Act $\$ 5($ b). SEN. Rep. No. 771, S0th Cong., 1st Sess. 11 (1947): "The unsatisfactory experiences of UNRRA with the use by recipient countries of proceeds from sale of relief goods led the committee to san with care the provisions for the sale of commodities when it considered the relief bill (Public Law 84) last spring. Because the matter had been so thoroughly explored at that time, the committee decmed it sound to incorporate the provisions of the relief bill in the present interim-aid bill." 
tion of internal financial and monetary conditions; and (c) development and expansion of raw material productive capacity. ${ }^{61}$

These counterpart clauses ${ }^{62}$ provided that for every United States dollar granted a commensurate amount of local currency would be deposited by the recipient country in a special account which could be used for relief and recovery projects. These local currency deposits could be retained in their accounts to retard inflation, or they could be channeled into projects, such as harbor improvement, improvement of transportation, erection of hydro-electric units and the retirement of national debt. ${ }^{63}$

There are several minor differences in the operation of these local currency provisions. The Relief Resolution required that a deposit of local currency equivalent to the sale price of the commodity be deposited in a revolving fund. ${ }^{64}$ In the Interim Aid Act ${ }^{65}$ and the Economic Cooperation Act, ${ }^{66}$ it was provided that a commensurate deposit in the currency of the recipient country be made when any commodity or service was furnished to a country on a grant basis. The local currency article of the 1948 Aid Act provided that the unencumbered balances of the deposits under the Relief Resolution and Interim Aid Acts be disposed of within such country for such purposes as were agreed to between such country and the Administrator in con-

61. H. R. Rep. No. 1585, 80th Cong., 2d Sess. 37 (1948). Sce also SEn. Rep. No. 935, 80th Cong., 2d Sess. 37 (1948), for the Senate Foreign Relations Committee's vicws and endorsement of a local currency provision in the Economic Cooperation Act which bccame $\S 115(b)(6)$ of that Act.

62. Relief Resolution §6; Interim Aid Act \$5(b); Economic Cooperation Act $\S 115(b)(6)$.

63. "Such special account . . . shall be held or used within such country for such pur"poses as may be agreed to between such country and the Administrator in consultation with the National Advisory Council on International Monetary and Financial Problems, and the Public Advisory Board provided for in section 107(a) for purposes of internal monctary and financial stabilization, for the stimulation of productive activity and the exploration for and development of new sources of wealth, or for such other expenditures as may be consistent with the declaration of policy contained in section 102 and the purposes of this title, including local currency administrative expenditures of the United States incident to operations under this title. .. ." Economic Cooperation Act $\$ 115(b)(6)$. SEN. REp. No. 13, 81st Cong., 1st Sess. 118, 119 (1949), sets forth the amounts of these funds through Nov. 30, 1948, and the amounts authorized for release by the United States Government. See also, for specific examples of the use of these funds, Economic Cooperatron ADMinistRatton, A Report on Recovery Progress and United States Aid 158-63 (1949).

64. "To the extent that relief supplies procured with funds authorized under this joint resolution are not furnished on terms of repayment in dollars, they shall be furnished oniy upon condition that the government of the receiving country agree that when it sells such relief supplies for local currency .... (a) the amounts of such local currency will be deposited by it in a special account. . . " Relief Resolution $\$ 6$.

65. Interim Aid Act $\$ 5(b)$.

66. Economic Cooperation Act $\$ 115(b)$ (6). 
sultation with the National Advisory Council on International Monetary and Financial Problems and the Public Advisory Board. ${ }^{\mathrm{CT}}$

To insure that the Congressional intent regarding local currency deposits would be carried out, the Economic Cooperation Act required that a local currency article be included in the bilateral agreements entered into with each country receiving grants under the Acts. ${ }^{c 3}$

In addition to the use of the local currency counterpart funds enumerated in the Economic Cooperation Act, ${ }^{6 \mathrm{cj}}$ an amendment that these funds shall be available for purposes to carry out the "declaration of policy contained in section 102" was incorporated in the amendatory bill, as reported by the Senate Foreign Relations Committee, and was included in the Amendments to the Economic Cooperation Act. ${ }^{70}$

The Foreign Aid Appropriation Act provided that not less than five per cent of these local currency accounts should be allocated to the United States for strategic materials or for other local expenses of the United States. ${ }^{71}$ A similar section was included in the Senate and House Committee bills to amend the Economic Cooperation Act, ${ }^{72}$ and it was subsequently included in the Amendments to the Economic Cooperation Act. ${ }^{73}$

67. See p. 903 infra.

68. Economic Cooperation Act $\$ 115(b)(6)$. See art. IV of Bilateral Agrecments. Agreements have been concluded with all participating countries except Switzerland and all these agreements except those with Portugal and Trieste are set forth in FmsT REport to Congress of the Econonic Cooperation Adamnistration, SUmplesteit (194S). The text of the agreement with Portugal is contained in the Seconso Rerost zo Costessess of the Econoasic Cooperation Adurnistration 119-28 (1948), trancmitted by the President to Congress on Feb. 11, 1949. The text of the agreement with UK/US Zons,

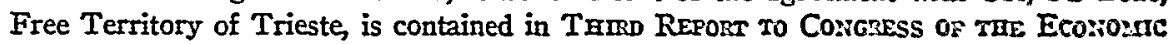
Cooperation Adarinistramion 89-98 (1949), transmitted by the President to Congress on May 16, 1949.

69. See note 63 supra.

70. S. 1209, S1st Cong., 1st Sess. \$10(b) (1949). SEx. ReP. No. 100, 81st Cong., 1st Sess. 14 (1949). 1949 Amendments to the Economic Cooperation Act $\$ 9(b)$, amending $\$ 115$ (b) (6) of that Act.

71. Foreign Aid Appropriation Act of 1949, Title I.

72. S. 1209, 81st Cong., 1st Sess. $\$ 10(c)$ (1949). SEx. REp. No. 100, 80th Cong., 1st Sess. 14, 15 (1949). H. R. 3748, 81st Cong., 1st Sess. \$9(b) (1949). Sce also Comptroller General's letter No. B-78647 of Aug. 3, 1948, concurring in the Administrator's interpretation of such section that it was applicable to "local currency administrative espenditures of the United States incident to operating under this title and any other lowal currency requirements of the United States Government and that ECA expenditures for administrative purposes or for the purchase of strategic materials made out of these special local currency accounts need not be matched by deposits of dollars with the United States Treasury." This 5\% provision was also included in art. IV of the agreements concluded with certain of the participating countries, sce note 68 sispro.

73. 1949 Amendments to the Economic Cooperation Act $\$ 9(d)$, becoming $\$ 115(h)$ of that Act. A further change in the local currency provision has been included in the proposed amendments to the Economic Cooperation Act by the introduction of a waiver of 


\section{Restrictions on Procurement}

The conditions and restrictions governing procurement incorporated in the relief acts reflect an interesting pattern in the development of Foreign Aid Legislation and reveal the increasing pressure to which Congress has been subjected as each successive statute was under consideration. Restrictions on procurement are designed to accord protection to the American taxpayer and the domestic economy, by the limitations and conditions attached to the procurement of aid commodities. These conditions included types of commodity, place of procurement and limitations on percentage of procurement permitted offshore or in the United States, depending upon whether the item is in surplus or in short supply in this country.

The Greek-Turkish Assistance Act did not deal with the source of procurement directly but contained provisions which indicated that most of the funds advanced would be spent in the United States. ${ }^{74}$ Thus there was no direct limitation on procurement in the GreekTurkish Act nor did the subsequent implementing agreement with Greece provide that procurement be in the United States. ${ }^{76}$

However, the Relief Resolution, passed only a few days after the Greek-Turkish Act, in effect required that at least 94 per cent of the funds appropriated be spent in the United States, since the commodities which could be procured offshore were limited to 6 per cent. ${ }^{70}$ Moreover, the place of procurement was specifically stated to be the United States in the agreements signed with Austria, Greece, Italy, and China. Section (c) of article I of these agreements provided that unless given specific approval all United States relief supplies should be prosured in the United States but did not mention its territories or poscessions. $^{77}$

Moreover, the intention of Congress to prefer procurement in the United States was reaffirmed in the Act appropriating funds for the 1947 Relief Resolution where it was provided:

"In making expenditures for foodstuffs from funds appropriated

such local currency deposits in the discretion of the Administrator with respect to technical information or assistance under $\$ 111$ (a) (3) and with respect to ocean transportation furnished under $\S 111$ in an amount not exceeding the amount as determined by the Administrator, by which the charges for such transportation exceed the cost of such transportation at world market rates. S. 1209, 81st Cong., 1st Sess. $\S 10(a)(1949) . H . R .3748$, 81st Cong., 1st Sess. $\$ 9$ (a) (1949). 1949 Amendments to the Economic Cooperation Act $\S 9$ (a), amending $\$ 115(b)(6)$ of that Act.

74. Greek-Turkish Assistance Act $\$ 2$ (a) (b).

75. Agreement on Aid to Greece signed at Athens, June 20, 1947, SEN. Doc. No. 111, 80th Cong., 1st Sess. 177-80 (1947); The Greer Aid Program (Dept. State Pub. No. 2939, Near Eastern Series No. 10) 22-5, app. V. (1947).

76. Relief Resolution \$2(a).

77. See note 38 supra. 
in this Act for relief abroad, it is the sense of the Congress that preference be given to the purchase, within the United States, of products, which can be purchased with benefit to the national economy, and that such purchases should include articles that are in surplus where possible and practicable." is

So completely was the emphasis on purchase within the United States, that no mention was made of the offshore purchase of petroleum products to conserve our dwindling domestic supply.

However, by the fall of the same year when the Interim Aid Act of 1947 was in draft form the short supply of many basic commodities led to an agreement by the House and Senate committees to increase from 6 per cent to 25 per cent the amount of goods which could be purchased offshore. ${ }^{79}$ Later, in conference it was decided that a limitation of 10 per cent would be proper, taking into consideration other provisions in the bill such as the direction to procure petroleum offshore wherever possible and the bill was passed with this 10 per cent limitation. Article I (2) of the agreements with Italy, France and Austria stated that procurement would be in the United States unless permitted to be procured elsewhere under section 4 of the Act. ${ }^{81}$

In addition, the shortage of petroleum and fuel oil portended to be particularly acute, and it was deemed advisable to incorporate a clause in the Interim Aid Act to encourage whenever practical the acquisition of petroleum and petroleum products from sources outside the United States, its territories and possessions. ${ }^{\text {s2 }}$

By the time the 1948 Foreign Assistance Act and its appropriation bill came before Congress for consideration, the stakes were sufficiently large to bring into play the pressures of numerous interests. And the Congressional concept of how to make the aid dollar go furthest was tempered with a desire to protect national interests. A number of specific procurement provisions were incorporated by the Congress in the enabling legislation ${ }^{83}$ and several more were added in the appro-

78. The Supplemental Appropriation Act of $1948 \$ 302$.

79. SEN. ReP. No. 771, S0th Cong., 1st Sess. 14 (1947), and H. R. REP. No. 1152, S0th Cong., 1st Sess. 4 (1947).

80. Interim Aid Act $\$ 4(2)$. See Comptroller General's letter to the Secretary of State of Feb. 25, 1948, interpreting this provision, in Second Report ro Co:igress 0:: rat United States Foreign Am Prograxs (Dept. State Pub. No. 3148, Economic Cooperation Series No. 8) 133-5 (1948).

81. See note 40 stpra.

82. Interim Aid Act $\$ 4(4)$.

83. Foreign Assistance Act $\$ 112$. This section is headcd "Protection of Domestic Economy." S. 1209, 81st Cong., 1st Sess. $\$ 7$ (a) (1949), reduced from 25\% to 15\% of the required percentage of flour to wheat shipped under the European Recovery Program as is provided in the Economic Cooperation Act $\$ 112(c)$. This percentage was reduced to $12 \pi / 2 \%$ in the 1949 Amendments to the Economic Cooperation Act $\$ 7(a)$. 
priation legislation. ${ }^{84}$ In addition to those procurement provisions incorporated in the Act, other amendatory provisions were unsuccessfully introduced which were intended either to protect certain United States short supply commodities or to ensure that the existing stocks in long supply or surplus would be procured with ECA funds. ${ }^{85}$

When considering amendments to the Economic Cooperation Act the Senate Foreign Relations Committee summarized their position on surplus as follows:

"It seemed clear to the committee that it would alter funda. mentally the nature and purpose of the recovery program if the Administrator were required to depart from the principle that the primary objective is assisting the recovery of Europe, and that this objective, in the interest of American taxpayers, must be accomplished at the lowest possible cost. This principle would be violated if provisions are written into the bill requiring the Administrator to use large amounts of surplus commodities or to finance payment for United States services, which are not needed for European recovery, particularly if such action would add substantially to the cost of the program. The committee, with these considerations in mind, did not accept any of these proposals to alter the basic character of the Economic Cooperation Act." 80

It is certain that during the life of the Marshall Plan, as the marginal producers in American industry are harder hit by European recovery, the pressure on Congress to grant special requests for the spending of ECA dollars will increase. It is to be hoped that Congress

84. "No funds available under this Act shall be used for the purchase of wool other than from existing stocks owned by the Commodity Credit Corporation, unless or until such stocks are exhausted." Foreign Aid Appropriation Act of $1949 \$ 202$.

"No part of the funds herein appropriated shall be used to purchase farm machinery, including tractors, in the United States in an amount which will bring the total exports of such machinery and tractors during the period for which this appropriation is made, from the United States, by or for the benefit of the countries participating in the European recovery program, to more than $\$ 75,000,000$." Id. $\$ 203$. See Comptroller General's Opinion, No. B-78650, July 30,1948, interpreting $\$ 203$ "as embracing exports from the United States of farm machinery including tractors whether financed from Economic Cooperation Administration funds or otherwise . .."

"Not less than 50 per centum of the United States export requirements of nitrogenous fertilizer materials or nitrogenous compounds (including anhydrous ammonia) for nonoccupied areas shall come from production of plants operated by or for the Department of the Army." Id. \$205.

85. See 94 CoNG. Rec. 7208 (1948). An amendment was introduced by Congressman Murray of Wisconsin to require ECA to purchase $\$ 65,000,000$ of dried milk solids. For a full discussion of the House and Senate Appropriation Committee's vicws, seo H.R. REp. No. 2173, 80th Cong., 2d Sess. 45 (1948) ; SEN. Rep. No. 1626, 80th Cong., 2d Sess. 10-1 (1948) ; H.R. REP. No. 2440, 80th Cong., 2d Sess. 1-6 (1948) (Conference Report to accompany H.R. 6801).

86. Sen. Rep. No. 100, 81st Cong., 1st Sess. 17 (1949). 
will follow the considered judgment of the Senate Foreign Relations Committee in adhering to the basic test that Recovery Program has as its primary objective the recovery of Europe, not the subsidization of domestic industry.

\section{Price Control}

In the expenditure of vast sums of money on foreign assistance, it was to be expected that Congress would include provisions for the control of prices and such provisions are to be found in the three most recent aid acts. These controls have been of two types-those upon purchase and those upon sale. Control of purchase price is important for several reasons: first, the lower the purchase price of commodities and services, the more aid per dollar; secondly, the effect of large-scale purchasing, itself inflationary, would be minimized if a curb were kept on the price of aid. The Relief Resolution contained no price provision per se. However, the bill appropriating funds for this relief stated that it was the sense of the Congress that preference be given to the purchase within the United States of products which could be purchased with benefit to the national economy and that such purchases should include articles that are in surplus, where possible and practicable. ${ }^{57}$

While there were no specific provisions in the 1947 Relief Resolution on price control upon disposition, one of the undertakings required of recipient countries was that a provision should be made for a control system so that all classes of people within the country would receive a fair share of supplies. ${ }^{38}$ Accordingly, the agreements entered into by each of the countries contained a clause providing for a ration and price control system, ${ }^{99}$ as well as a provision that the prices at which the goods were sold would be agreed to between the United States and the recipient country. ${ }^{90}$

When the Interim Aid Act was under consideration during November and December of 1947 and the full impact of permanent aid on the domestic economy was perceived, the question of prices received a fuller consideration. As a result, the Interim Aid Act was passed, replete with price provisions. One clause provided that the President should promulgate regulations controlling the purchase or procurement of commodities under the Act designed to minimize (a) the drain upon the natural resources of the United States, and (b) the impact of such

87. See pp. 886-7 supra.

88. Relief Resolution $\$ 3(\mathrm{~h})$.

89. See art. II (f) of agreements listed in note $3 S$ supra. In the agreement between the United States and Italy, July 4, 1948, art. II (f), the wording was slightly different stating that distribution should be such that all classes of population irrespective of purchasing power should receive their share.

90. See id., art III (a). 
purchases upon the domestic price level. ${ }^{01}$ Moreover the Act provided that procurement could be from foreign sources whenever the cost of delivery to the recipient country would be less than the cost of delivery from the United States. This in effect made the test one of lowest delivered price. Another section provided:

"That, except in the case of commodities not produced in commercial quantities in the United States, not more than 10 per centum of the funds made available under the authority of this Act may be used to procure commodities abroad at delivered cost higher than from the United States, its Territories and possessions, provided that the President shall find that such commodities are in short supply or not readily available in the United States. . . ." 02

A further proviso enacted that no funds made available under the Act should be used to purchase commodities within the United States, its territories or possessions, at prices higher than the market price prevailing at the time of the purchase in the area wherein the purchase was made. ${ }^{93}$ The Act also directed that petroleum be delivered by the most economical route and the Comptroller determined that the petroleum was included under the 10 per cent limitation on delivered price to recipient countries. ${ }^{94}$

The Interim Aid Act, as well as the agreements concluded thereunder, contained provisions limiting the price at which commodities could be sold, the Act requiring that a recipient country should sell to its people at reasonable prices ${ }^{95}$ commodities furnished under the Act. The agreements with France, Italy and Austria contained articles in which the governments acknowledge this undertalking to make the aid goods available to its people at reasonable prices.90

The Economic Cooperation Act contained no price provisions, but the Appropriation Act ${ }^{97}$ contained a restriction in the purchase price of bulk commodities in section 202, which provides as follows:

"No funds made available under the authority of this Act shall

91. Interim Aid Act $\$ \$ 4(2)$ and 4(4).

92. Id. $\$ 4(2)$. As of Sept. 30,1948 , the requisitioned value of supplies purchased abroad, where the delivered cost was higher than if procurement had been made in the United States, its territories, or possessions, was $\$ 56,532,000$, well within the $10 \%$ limitation specified. An additional sum of $\$ 64,172,878$ was authorized for off-shore purchascs, but since their delivered cost to the recipient country was less than the delivered cost from the United States, these purchases were outside the 10\% limitation. Sce SEcond Report to Congress of the Economic Cooperation Administration 114 (1948).

93. Interim Aid Act $\$ 4(2)$ :

94. See letter of Comptroller General interpreting this provision, note 80 supra.

95. Interim Aid Act $\$ 5(\mathrm{e})$.

96. See note 40 supra. Art. II of these agreements states that the government of the recipient country "will perform the undertaking specified in $\$$ 5."

97. Foreign Aid Appropriation Act of $1949 \S 202$. 
be used for the purchase in bulk of any commodities . . . at prices higher than the market price prevailing in the United States at the time of the purchase adjusted for differences in the cost of transportation to destination, quality and terms of payment."

The Foreign Aid Appropriation Act, as passed by the House of Representatives, provided in section 202 that no funds should be available for the purchase of any commodities at prices higher than the market price prevailing in the United States at the time of purchase, but this language was deleted by the Senate Committee as being unworkable, and the language of the Act as passed was substituted. ${ }^{.3}$

The Comptroller General took the position in a letter to the Administrator of August 4, 1948 that:

"Nowhere in the hearings, reports, or debates on the bill is it suggested that the applicability of section 202 was intended to be determined by the type of commodities purchased. If, as seems evident, the purpose of the section was to establish a price limitation, the criterion for determining its applicability properly should be based on the quantity of goods purchased rather than on their character. In view of the foregoing, I am of the opinion that the restrictions of section 202 are applicable to purchases in large quantities of all commodities." 93

The Administrator found the provisions of the bulk price section satisfactory during the first year of operation and it was included in the suggested amendments to the Economic Cooperation Act under the section on protection of domestic industry. ${ }^{109}$

98. See SEN. ReP. No. 1626, S0th Cong., 2nd Sess. 11 (1948), for committec's comment on price policy:

"The committee believes that no funds made available under this act should be used to purchase commodities, except under limited special circumstances, at more than the current market price in the United States at the time of the purchase, maling adjustments for differences in the cost of transportation to destination, quality, and terms of payment. Limited deviation from this rule will be justified in special situations as, for example, for off-shore purchases when purchases in the United States might materially force up the market price because of insufficient supply, or in which the Department of Commerce might feel that export licenses should not be granted, or for domestic purchases from the Commodity Credit Corporation.

"The committee recognizes that any direct prohibition of such purchases would present an almost insurmountable task of policing if every transaction made through private channels is to be checked. Some check might be furnished by requiring a certificate from the supplier that the price charged by him was not in excess of the current market price at the time.

"Some deviations from this general price policy will normally occur in the ordinary course of business. However, the Administrator is expected to limit strictly material deviations from this general price policy. Flagrant or constant violations shall be considered by him as reason to employ sanctions contained in section 118 of the aet."

99. Opinion of Comptroller, No. B-78649 of Aug. 4, 1948.

100. S. 833, 81st Cong., 1st Sess. $\$ 6(b)(1949)$. The language of the Foreign Aid Appropriation Act of $1949 \S 202$ has been used. 
The respective committees endorsed the Administrator's suggestion by including it in the bill to amend the Economic Cooperation Act as reported to the House and Senate, and it was incorporated without change in the amendments to the Act. ${ }^{101}$ The Administrator has taken the position that this price provision establishes an upper limit to the prices that may be approved by ECA for purchases in bulk of commodities and that it is the policy of ECA to make payment only for purchases of commodities, whether or not in bulk, which are made at prices that approximate, as nearly as practicable, lowest competitive market prices. ${ }^{102}$ It would seem that with the return of a 'buyers' market" prices generally should be kept in line by the increased competition between vendors, though the danger of large industries maintaining prices at artificially high levels is ever present.

\section{Assistance to Individuals and Agencies Forwarding Voluntary Relief Supplies}

Congress has recognized the great contribution made by individuals and by voluntary non-profit relief organizations in supplying food, clothing and medicine to the needy of war-torn countries and in two aid acts has provided for the total or partial payment of ocean freight or postage. Under the Relief Resolution, $\$ 5,000,000$ was authorized to be appropriated to pay the necessary expenses related to ocean transportation of supplies purchased by American voluntary and nonprofit relief agencies in such quantities and kinds as the President determined were essential supplements to the assistance to be furnished under the Act. ${ }^{103}$

The Supplementary Appropriations Act of 1948 specifically provided that its appropriation of $\$ 332,000,000$ for Public Law 84 should be available for the transportation of voluntary relief supplies shipped by relief agencies licensed for operation in Europe and in Asia including the occupied areas under such regulations as the Secretary of State should prescribe. ${ }^{104}$

The Interim Aid Act of 1947 contained no such provision, presumably because $\$ 5,000,000$ authorized in the spring of 1947 and appropriated on July 30,1947 was still sufficient to defray the transportation costs of such supplementary relief shipments as were being made.

This assistance to individuals who were extending a generous and

101. S. 1209, 81st Cong., 1st Sess. §7(b) (1949). SEN. REp. No. 100, 81st Cong., 1st Sess. 10 (1949). H.R. 3748, 81st Cong., 1st Sess. $\$ 7$ (d) (1949). 1949 Amendments to the Economic Cooperation Act $\S 7(d)$, amending $\S 112$ of that Act.

102. See note 68 supra. ECA Reg. No. 1, § 201.22, as amended May 3, 1949, 14 FED. REG. 2166 (1949).

103. Reilief Resolution $\$ 2(f)$.

104. The Supplemental Appropriation Act of 1948, "Relief Assistance to War Devasted Areas." 
helping hand to those less fortunate was strongly endorsed during the consideration of the long-range recovery program, and consequently a section on relief supplies was incorporated in the Economic Cooperation Act of 1948,105 authorizing the Administrator under rules and regulations prescribed by him ${ }^{100}$ to pay ocean freight charges from a United States port to a designated foreign port of entry of supplies donated to or purchased by United States voluntary and non-profit relief agencies registered with, and recommended by, the advisory committee of voluntary foreign aid for operations in Europe.

By the same section, ${ }^{107}$ the Administrator was directed to make an agreement with such country for the use of a portion of the deposit of local currency to defray the transportation cost of such supplies from the port of entry to the designated shipping point of consignee.

The Secretary of State was also directed by the same section, after consultation with the Administrator, to make arrangements, where practicable, with the participating countries for the free entry of such supplies and relief packages. As of April 1, 1949, agreements for the use of local currency to defray inland transportation costs and the free entry of relief packages had been entered into between the United States and nine of the participating countries. ${ }^{109}$

\section{Reparations}

The problem of reparations as it might affect or be affected by foreign assistance legislation was first considered by Congress in connection with the Relief Resolution. ${ }^{109}$ The Relief Resolution stated that when supplies were transferred or otherwise made available to any country pursuant to the resolution the President should cause representatives of the Government of the United States " . . . to seek arrangements that reparations payable from current production by any such country to any other country by treaty be postponed during the period of such relief." 110

105. Foreign Assistance Act $\$ 117(c)$, and Foreign Aid Appropriation Act of 1949 tit. I.

106. ECA Reg. No. 2, 13 FED. REg. 3728 (1948) (Parcel Post Shipments of Individual Relief Packages); ECA Reg. No. 3, 13 FED. REg. 3783 (1948) (Commercial Freight Shipments of Supplies by Voluntary Non-Profit Relief Agencies); ECA Reg. No. 5, as amended, 13 FED. REG. 4705 (1948) (Ocean Freight Shipments of Individual Relief Packages).

107. Foreign Assistance Act $\$ 117$ (c). See 1949 Amendments to the Economic Cooperation Act $\$ 10(a)$, amending $\$ 117$ (c) of that Act to provide that the Administrator pay a uniform rate per pound for ocean transportation of all relief paclisges.

108. Agreements have been concluded with Austria, Feb. 16, 1949; Bizone of Germany, Dec. 15, 1948; France, Dec. 23, 1948; French Zone of Germany, Feb. 7, 1949; Grcece, Feb. 9, 1949; Italy, Nov. 26, 1948; the Netherlands, Jan. 19, 1949; Trieste, Feb. 11, 1949; and the United Kingdom, Dec. 1, 1948.

109. H. R. REP. No. 395, S0th Cong., 1st Sess. 10 (1947).

110. Relief Resolution $\$ 4(3)$. 
No mention was made of reparations in the Interim Aid Act, but the Economic Cooperation Act contains a requirement that the Administrator "request the Secretary of State to obtain the agreement of those countries concerned that such capital equipment as is scheduled for removal as reparations from the three western zones of Germany be retained in Germany if such retention will most effectively serve the purposes of the European Recovery Program." 111 The emphasis thus shifted from postponement of current reparations to permanent retention of capital equipment heretofore scheduled for removal as reparations from the three western zones of Germany, for Congress realized that effective utilization of German industry was necessary to speed European Recovery.

The Senate Committee on Foreign Relations had already gone on record in its report on the draft aid bill that it was "satisfied that the policies of this Government with respect to dismantling of German plants are consistent with the European Recovery Program and that they do not jeopardize the vital role that Western Germany is required to play under the program." The committee went on to observe that the industrial capacity represented by the non-war plants cannot be used in Germany within the period of the recovery program because of shortages of raw materials, transport, manpower, and other factors which hamper the expansion of German production. ${ }^{12}$ The House Foreign Affairs Committee, however, incorporated the reparations section, as it was ultimately enacted in the Economic Cooperation Act, stating that in view of the fact that the removal program was the subject of multilateral agreements to which the United States was a party the committee was convinced that this was as far as it could go in seeking a reexamination of the removal program. ${ }^{113}$ In order to advise him concerning reparations and the dismantling of German war plants the Administrator appointed a committee ${ }^{114}$ which studied the dismantling problem in the field in the latter half of 1948 and made their report and recommendations to the Administrator in January, 1949.

The Administrator requested the Secretary of State to obtain the agreement of the countries concerned to the retention in Germany of the plants recommended by the committee in the interests of the

111. Foreign Assistance Act $\& 115$ (f).

112. SEn. REp. No. 935, 80th Cong., 2d Sess. 39, 40 (1948). The Senate Forcign Relations Committee again stressed their position in this matter in the report on S. 1209, saying:

"[T] he committee ... stresses once more the desirability of not removing from Germany those plants which, if retained, will most effectively contribute to European Recovery." Sen. Rep. No. 100, 81st Cong., 1st Sess. 20 (1949).

113. H. R. Rep. No. 1585, 80th Cong., 2d Sess. 99 (1948).

114. The members of this Committee were George M. Humphrey, Frederic V. Geicr, John L. McCaffrey, Gwilym A. Price and Charles E. Wilson. 
European Recovery Program, and these recommendations formed the basis for an inter-governmental agreement, concluded April 5, 1949, to the effect that 159 plants, or parts of plants, previously scheduled for removal as reparations were to be retained in Germany. ${ }^{115}$

\section{Quarterly Reports}

It was fitting that the Congress should require from the executive branch of the Government an account of the progress being made under each of the aid acts. ${ }^{116}$ Consequently, a provision requiring the President to make quarterly reports of the activities and expenditures under the various aid acts has been incorporated in each act. ${ }^{117}$ Quarterly reports for the first three aid acts were published by the Department of State as a part of their Near Eastern Series and Economic Cooperation Series and contained full resumes of the operational aspects of the various assistance programs. ${ }^{113}$ The first three quarterly reports on the Foreign Assistance Act of $1948{ }^{110}$ have been transmitted by the President to Congress. ${ }^{120}$

The Administrator also prepared a full report for the use of members of Congress in their consideration of the continuance of foreign aid, ${ }^{121}$ which was in the nature of a cumulative quarterly report.

\section{Termination of Aid}

Realizing the rapidly changing political and economic considerations which presently prevail or may come to prevail in countries receiving assistance, the Congress has forehandedly included in all aid acts a provision for termination of aid if circumstances dictate. ${ }^{122}$ This

115. Econontc Cooperation Adnmistration, A Refort on Reconeri Progriss aid United States Am 240 (1949). See also ECA Press Release No. 526, April 13, 1949.

116. The first reports on the Greek-Turkish Assistance Act of 1947 vere printed as part of the Near Eastern Series, see notes 38, 75 supra.

117. Greek-Turkish Assistance Act $\$ 7$; Relief Resolution $\$ 7$; Interim Aid Act of 1947 \$13; Foreign Assistance Act $\$ 123$.

118. These reports, referred to throughout this article, are published by the Department of State; they contain complete information on the various Acts for the quarters they cover.

119. "The President from time to time, but not less frequently than once every ealendar quarter through June 30,1952 , and once every year thereafter until all operations under this title have been completed shall transmit to the Congress a report of operations under this title . . ." Foreign Assistance Act $\$ 123$.

120. The first report, covering the period ending June 30, 1948, was transmitted to Congress by the President on Oct. 4,1948 . The second quarterly report, for the period June 30 to Sept. 30, 1948, was transmitted to Congress on Feb. 11, 1949. The third quarterly report, for the period ending Dec. 31, 1948, was transmitted to Congress on Miay 16, 1949.

121. Economic Cooperation Administration, A Repont on Reconzzy Pfogness aid UNITED STATES Am.

122. Greek-Turkish Assistance Act $\$$ 5. The language directed the President to vithdraw any or all aid "under certain circumstances." Relief Resolution \$5(3) stated: 
right of termination was not exercised under the first three acts ${ }^{123}$ but was exercised in part within nine months of the passage of the Economic Cooperation Act. The occasion was the renewal of armed conflict in the Netherlands East Indies.

On December 22, 1948, the Administrator suspended the issuance of authorizations for the procurement of supplies destined to be used in Indonesia, stating that:

"ECA funds can appropriately be spent for the shipment of supplies to Indonesia only if there is reasonable assurance that United States aid can be distributed efficiently among the people of Indonesia and that it will contribute to economic recovery there and in Europe. Pending clarification of the present situation in Indonesia, it is impossible to determine whether the economic assistance program can be effective in these respects. Until this determination is made, the further commitment of ECA funds would be unjustified." ${ }^{24}$

When amendments to the Economic Cooperation Act were being considered the problem of Indonesia was carefully reviewed by the House Foreign Affairs and Senate Foreign Relations Committees, the former concluding that "the act already contains all that needs to be said about the relationship of the program to the United Nations, and the inclusion of language to make the program a possible instrumentality of sanctions would be redundant." ${ }^{225}$

However, Senator Brewster introduced an amendment on the floor of the Senate during the debates on the Bill which provided that no funds authorized for the purposes of the Act should be allocated to a foreign government which failed to comply with the order or requests of the Security Council of the United Nations. ${ }^{126}$ Subsequently a

"The President shall promptly terminate the provision of relief assistance whenever he determines ....,-listing causes for termination.

Interim Aid Act $\S 6$, provided: "The President shall promptly terminate . . , "-listing causes. Termination is also listed under "General Functions of Administrator," Foreign Assistance Act $\$ 105$ (a) (4).

123. Although Poland and Fungary were listed as countries entitled to relief assistance under the Relief Resolution, no aid was extended to either country.

124. See ECA Press Release No. 330, Dec. 22, 1948, carrying Mr. Hoffman's announcement suspending the issuance of authorizations for the procurement of supplics destined to be used in Indonesia. See also SEN. REp. No. 13, 81st Cong., 1st Sess. 74 (1949). As of April 1, 1949, the situation in Indonesia had not been clarified and the suspension was still effective.

125. H.R. Rep. No. 323, 81st Cong., 1st Sess. 13 (1949). See also SEn. Rer. No. 100, 81st Cong., 1st Sess. 20-1 (1949).

126. "No funds authorized for the purposes of this act shall be allocated to or expended for any foreign government which fails to comply with the orders or requests of the Security Council of the United Nations until such times as the Administrator is advised, in writing, by the president of the Security Council that such compliance has been effected." 95 Cong. Rec. 4073 (1949). 
modified Brewster amendment was introduced which required the Administrator to terminate assistance to any country when "such assistance would be inconsistent with the obligations of the United States under the Charter of the United Nations to refrain from giving assistance to any State against which the United Nations is taking preventative or enforcement action." 127

In conference the managers on the part of the House receded and accepted the modified Brewster amendment stating that "the language accepted in the bill as reported by the committee of conference in no wise exposes the United States to the obligation to act alone in applying economic sanctions to any country." 123

Congress has thus seen fit to amend the termination section of the Economic Cooperation Act to reflect the practical problems posed by political as well as purely economic considerations.

As has already been mentioned there was temporary suspension of aid under the Economic Cooperation Act, due to the failure of several participating countries to conclude bilateral agreements with the Secretary of State within three months after the passage of the Act. ${ }^{153}$ This section stated that the Administrator during the three months after the date of enactment might perform any of the functions under the Act if such country signified its adherence to the purposes of the Act and its intention to conclude a bilateral agreement. The allotted three months expired on July 3,1948 and temporary suspension of aid was necessary in the case of several countries which had not concluded the bilateral agreements. However, assistance was again extended as soon as these countries had concluded the bilateral agreements. In some instances the agreements had been signed within the three months by the executive branch of the various governments but had not been ratified by the legislative bodies. ${ }^{130}$

\section{Provisions First InCORPorated IN THE ECONOAIIC COOPERATION ACT OF 1948}

Having examined the provisions common to the Economic Cooperation Act of 1948 and one or more of the preceeding aid acts, there remain for consideration provisions peculiar to the Act of 1948. This section will discuss the most salient of these provisions, which include the establishment of a separate agency to administer foreign aid; cooperation with an international organization in planning for European

127. 1949 Amendments to the Economic Cooperation Act $\S 11$, amending $\S 118$ of that Act.

12S. H.R. RFp No. 440, 81st Cong., 1st Sess. 12-3 (1949).

129. Foreign Assistance Act $\$ 115$ (c). Prior to the conclusion of the agrecments, aid was extended upon letters of intent to conclude such agreements. See also Surrey, The Economic Cooperation Act of 1948, 36 CALIF. I. REv. 509, 555 (1948), and note 42 sufro. 130. See p. 879 stpra. 
recovery; procurement procedures emphasizing utilization of the private channels of trade; instructions for the Administrator to consult with advisory bodies; direction to use United States flag vessels for 50 per cent of the cargoes; the encouragement of travel by United States citizens in participating countries; the establishment of a Joint Congressional Committee; provision for the guaranty of convertibility of currency of investments by United States Citizens and provisions for acquisition of strategic materials. ${ }^{131}$

\section{The Establishment of a Separate Agency to Administer the Economic Cooperation Act of 1948}

Whether to designate an existing department or agency, or create a new agency to administer the long-range recovery program, presented a problem of first magnitude. The previous aid acts had been administered by the State Department with requisite assistance from other governmental departments and agencies. The State Department had been designated by Executive Order ${ }^{132}$ to administer and carry out the provisions of the Greek-Turkish Assistance Act of 1947, and subsequently, the Relief Resolution provided ${ }^{133}$ that the authority of the President granted by sections 2, 3 and 4 of the Resolution might be exercised by the Secretary of State. The President on May 31, 1947 delegated his authority to the Secretary of State. ${ }^{134}$

Similarly the Interim Aid Act of 1947 provided ${ }^{135}$ that the President could delegate any of the powers conferred on him by the Act

131. Foreign Assistance Act $\$ 110$ (c) requires that: "No citizen or resident of the United States may be employed, or if already employed, may be assigned to duties by the Secretary of State or the Administrator under this title for a period to exceed three months unless such individual has been investigated as to loyalty and security by the Federal Bureau of Investigation and a report thereon has been made to the Secretary of State and the Administrator, and until the Secretary of State or the Administrator has certified in writing (and filed copies thereof with the Senate Committee on Foreign Relations and the House Committee on Foreign Affairs) that, after full consideration of such report, he believes such individual is loyal to the United States, its Constitution, and form of government, and is not now and has never been a member of any organization adrocating contrary views. This subsection shall not apply in the case of any officer appointed by the President by and with the advice and consent of the Senate."

Greek-Turkish Assistance Act $\$ 1(2)$ provided: "no civilian personnel shall be assigned to Greece and Turkey to administer the purposes of this Act until such personnel have been investigated by the Federal Bureau of Investigation."

No attempt will be made in this article to discuss the loyalty section of the Economic Cooperation Act. For recent comments on the loyalty problems, see, Emerson and Helfeld, Loyalty Among Government Employees, 58 YALE L. J. 1 (1948) and Hoover, A Comment on the Article "Loyalty Among Government Employees," 58 YALE L. J. 401 (1949).

132. Exec. Order No. 9864, 12 FEd. REg. 3559 (1947).

133. Relief Resolution $\$ 4$.

134. Exec. Order No. 9864, 12 FEd. REg. 3559 (1947).

135. Interim Aid Act $\$ 10$. 
to the Secretary of State and this delegation was made on December 26, 1947. ${ }^{136}$ Moreover, the possibility that a new organization might be created to carry on the long-range recovery program was recognized in the Interim Aid Act which provided that its functions, applicable records and funds could be transferred to the administration of any organization for general foreign aid which Congress might provide. ${ }^{137}$

Although the Administration Bill drafted by the State Department, the Senate Bill, and the Herter Bill each provided for a new, separate agency to administer the aid program, ${ }^{13 s}$ the question was crucial enough to the success of the entire program that the Senate Committee on Foreign Relations requested the Brookings Institution to prepare a special report as to the various ways the foreign aid program could be administered. ${ }^{139}$

The Institution's recommendation that a separate agency be established ${ }^{1 \leqslant 0}$ was ultimately included in the Economic Cooperation Act. ${ }^{141}$ Moreover, the Institute favored a non-corporate form of agency, ${ }^{142}$ but as the Act was passed the Administrator was authorized and empowered "to create a corporation with the approval of the President" ${ }^{143}$ though as yet the Administrator had not seen fit to request such approval from the President. ${ }^{144}$

It is apparent that the myriad problems which confront any government agency will be experienced during the life of ECA and the building of an organization capable of discharging the duties devolving upon it was one of the most important tasks confronting Mr. Hoffman when he assumed the position of Administrator in April of 1948. As

136. Exec. Order No. 9914, 12 Fed. REg. \&\$67 (1947). For a detailed deseription of the manner in which the State Department discharged its stewardship of the Relief Resolution of 1947 and the Interim Aid Act of 1947, see H.R. Rep. No. 1845, E0th Cong, 2d Sess. 758-63 (1948).

137. Interim Aid Act $\$ 14$. Such transfer was actually effected by Exee Order NTo. 9960, 13 FED. REG. 2707 (1948).

138. Analysis of Foreign Aid Proposals, Committee on Foreign Affairs, Stafi Memorandum 41 (1947).

139. The committee made its request on Dec. 30,1947 , and the Broolings Institution submitted its report on Jan. 22, 1948.

140. Id. at 15.

141. Economic Cooperation Act $\$ 104$.

142. Report of the Brookings Institution, supra note 139, at 16.

143. Economic Cooperation Act $\$ 104$ (d). For analysis of the difference between the corporate form and non-corporate form of government agency, see H.R. REP. No. 1S45, 80th Cong., 2d Sess. 776-84, app. E and F (1948) which set forth the Comptroller General's Letter of Dec. 5, 1947 (No. B-34706), and Bureau of the Budget Staff Memorandum of Dec. 2, 1947 to Representative Eaton as Chairman of the House Forcign Afiairs Committee in response to his inquiry to them of Nov. 24, 1947 on this subject.

144. See H.R. ReP. No. 1585, S0th Cong., 2d Sess. 81 (194S), for House Committee's opinion that flexibility would be achieved if the Administrator was empowered to create a corporation with the approval of the President. 
of the present time, there are over eight hundred employees in Washington, over seven hundred in Paris, and more than a thousand in the ECA Country Missions. The ECA personnel abroad have been employed under section 110 (a) (2) of the Act and as such are members of the Foreign Service Reserve and Staff. ${ }^{145}$

\section{Cooperation with the OEEC}

An articulate and influential body designed to plan European recovery had been envisaged at Paris in July, 1947.146 On April 16, 1948, the Office of European Economic Cooperation became a going concern, less than a fortnight after its American partner, the Economic Cooperation Administration, was created by Congress. United States governmental agency collaboration with an international organization of which the United States was not a member created an unusual operational relationship which was a challenge to the capabilities of ECA's administrative staff. ${ }^{147}$

The articles adopted by the Convention for European Economic Cooperation state that the contracting parties agree that: "As their immediate task they will undertake the elaboration and execution of a joint recovery program," ${ }^{148}$ and "will, within the framework of the organization and as often and to such extent as may be necessary, draw up general programs for the production and exchange of commodities and services." 149

Since the program figures originate with OEEC, ECA is placed in the unique position of having to ask Congress for an appropriation based upon estimates made by an organization in which the United States Government has no formal representation. These OEEC estimates on European needs are of course subject to revision by the Administrator. Still the impetus comes from a foreign source. Anticipating possible dangers in this situation, Congress was careful to provide in the Act that the Administrator could not delegate to any international agency any of his authority to decide the method of furnishing assistance or the amount thereof. ${ }^{150}$

145. Foreign Assistance Act $\$ 110$ (a) (1) permitted the Administrator to employ persons directly, but it was felt expedient to utilize the well-established procedures of the State Department in connection with ECA personnel abroad so the proccdure of $\S 110$ (a) (2) has been followed by the Administrator.

146. See p. 876 supra.

147. The authority to request the cooperation of an international organization or agency is conferred by Foreign Assistance Act $\S 121$ (a).

148. Convention for European Economic Cooperation with Related Docunents

(Dept. State Pub. No. 3145), art. I (1948) (cited hereafter as ConvENTtoN).

149. Id. art. III.

150. Foreign Assistance Act $\$ 121$ (a). The second annual program for the fiscal year 1949-50 will not be completed until the spring of 1949. The OEEC has obtained program submissions for 1949-50 from each of the participating countries but it does not plan to 
The Administrator's special representative in Paris is in a position to consult with OEEC members but his power to influence the OEEC decisions is on an informal basis only. However, OEEC has passed a resolution on the relation between that organization and the United States Special Representative in Europe recommending that OEEC should make all such arrangements as may be appropriate to maintain close relationships with the United States Special Representative in Europe, appointed in accordance with the United States Economic Cooperation Act of 1948, and to assist him in the performance of his duties. 151

In addition to these functional aspects of OEEC, which must mesh with the operations of ECA if the Recovery Program is to succeed, membership in the OEEC has been made a condition precedent to the eligibility of a country to receive aid under title I of the Foreign Assistance Act of $1948 .{ }^{152}$

For example, Spain could not be added to the list of countries receiving aid under the Economic Cooperation Act of 1948 until it had first become a member of the OEEC. When resolving the differences in the Senate and House on the Act, the conference committee felt it wiser not to mention Spain or any other specific country which might become a participant in the recovery program upon fulfilling the required conditions for membership in OEEC. ${ }^{153}$

The convention for European Economic Cooperation provided that any non-signatory European country could accede to the OEEC by giving notice addressed to the Government of the French Republic and upon the assent of the Council of the Organization. ${ }^{154}$ To date,

undertake the detailed revision and coordination of these programs until the Congress has indicated what the maximum extent of American assistance may be and until the worl: can be accomplished with a clearer view of the needs of the long-term program for Western Europe. See Econositc Cooperation Adarinistration, A Refort ori Rrconery ProgRESS AND UNTTED STATES ATD 95-6 (1949).

151. CONVENTION, Res. No. 2.

152. Foreign Assistance Act $\$ \S 102(a), 103$ (a).

153. H.R. REp. No. 1655, S0th Cong., 2d Sess. 27 (1948). The committee report states in part: "In conference it was felt wiser not to mention Spain or any specific country which might become a participant by fulfilling the required conditions.

"The merits of the question of including Spain are not being passed upon. This enterprise is open to Spain whenever the participating countries desire to have Spain enter the partnership. Under the theory upon which the partnership has been launchcd and organized, the United States leaves to the participating governments the initial decision on the admission of a new partner.

"Nothing in the bill closes the door on Spain's participation. In the view of the managers on the part of the House, it is unnecessary to attempt to open a door that has never been closed in this legislation."

See also SEN. REp. No. 935, 80th Cong., 2d Sess. 13 (1948): "Whether she [Sprin] eventually takes part in the program will depend upon her own willingness to assume the obligations involved, the willingness of the participating countries to admit her and the ability of Spain to conclude a satisfactory bilateral agreement with the United States."

154. Convention, arts. 25, 28. 
the British/United States Zone of the Free Territory of Trieste is the only European "country" which has applied for admission, and the accession of this Zone to OEEC took place on October 15, 1948.165

\section{Direction to Consult with Advisory Groups}

Due to the magnitude and the ramifications of the business to be carried on by ECA, it was unlikely that the Administrator would find within his own agency all the expert advice so necessary in forming a judgment on the many complex operational problems with which he would be faced. Recognizing this, Congress has directed the Administrator to consult with two specifically designated public and private advisory groups, and has encouraged the Administrator to appoint advisory committees when he deems it necessary. ${ }^{160}$

One of the two advisory groups named, the National Advisory Council on International Monetary and Financial Problems, ${ }^{167}$ was constituted by the Bretton Woods Agreements Act ${ }^{158}$ to coordinate and develop United States international financial and monetary policy, and especially the policies of United States representatives on the International Monetary Fund and the International Bank. The Secretary of the Treasury is the Chairman of the NAC; other departments and agencies represented on the Council are State, Commerce, Agriculture, Federal Reserve System and Export-Import Bank and the Administrator for Economic Cooperation. The Economic Cooperation Act of 1948 was the first legislation in which Congress directed that the head of a government department or agency consult with the NAC, and it was recognition that the problems of the Act required expert knowledge of international monetary and fiscal matters.

In the administration of financial assistance under the Act the

155. The Bilateral Agreement with the British/United States Zone, Free Territory of Trieste was also signed on Oct. 15, 1948, for under the terms of the Foreign Assistance Act $\S 103(\mathrm{~b})$, Trieste could not have continued to receive aid after becoming a member of OEEC unless a bilateral agreement was concluded.

156. Foreign Assistance Act $\S 107$ (a) (b), 111(c) (1) (2), 115(b) (6).

157. See note 52 supra.

158. 59 Star. 512 (1945), 22 U.S.C.A. $\$ 286$ (Supp. 1948). The Foreign Assistance Act $\S 105$ amends $\$ 4$ (a) of the Bretton Woods Agreements Act to read as follows:

"Sec. 4. (a). In order to coordinate the policies and operations of the representatives of the United States on the Fund and the Bank and of all agencies of the Government which make or participate in making foreign loans or which engage in foreign financial, exchange or monetary transactions, there is hereby established the National Advisory Council on International Monetary and Financial Problems (hereinafter referred to as the 'Council'), consisting of the Secretary of the Treasury, as Chairman, the Secretary of State, the Secretary of Commerce, the Chairman of the Board of Governors of the Federal Reserve System, the Chairman of the Board of Directors of the Export-Import Bank of Washington, and during such period as the Economic Cooperation Administration shall continue to exist, the Administrator for Economic Cooperation." 
Administrator is instructed to consult with the $N A C,{ }^{159}$ in determining whether such assistance shall be through grants, or upon terms of payment, and in determining the terms of payment. ${ }^{110}$ The succeeding section of the Act reiterates that the Administrator shall malie and administer the credit on terms specified by the Administrator in consultation with the NAC. ${ }^{161}$ The Administrator is also directed by the Foreign Assistance Act of 1948 to consult with the NAC in reaching agreements with the participating countries on the use of counterpart funds. ${ }^{162}$ With the counterpart equivalent of billions of dollars to be expended by the participating countries the determination as to the manner in which these funds are to be expended is one of great responsibility and importance in most effectively and expeditiously achieving European recovery. In addition the Administrator has consulted with the NAC in establishing formulae for ascertaining the rates of exchange at which currencies of the participating country presented by the investor for transfer under contracts of guaranty would be converted into dollars. 163

The second of these statutory advisory groups, the Public Advisory Board, was to be composed of a group of twelve citizens of the United States with the Administrator as the Chairman. ${ }^{104}$ In addition to the Administrator's duty to consult with them on the use of local currency, the Board "shall advise and consult with the Administrator with respect to general or basic policy matters arising in connection with the Administrator's discharge of his responsibilities." 105 The Board has advised the Administrator in several matters on which he has followed their advice in reaching his decision. In deferring action on the 50 per cent shipping clause, the Administrator acted upon the

\footnotetext{
159. See note 52 supra.

160. Foreign Assistance Act $\$ 111$ (c) (1).

161. Id. $\$ 111(\mathrm{c})(2)$.

162. Id. $\$ 115(\mathrm{~b})(6)$.

163. See page 914 infra for discussion of guaranty provisions of the Foreign Assistance Act.

164. Foreign Assistance Act $\$ 107$ (a). Referred to hereinafter as the Board. The present members of the Board are: Sarah G. Blanding, President of Vassar College, James B. Carey, Secretary-Treasurer of the Congress of Industrial Organizations, Jonathan W. Daniels, Editor of the News and Observer, Raleigh, N. C., Albert S. Goss, Mfaster of the National Grange, Robert H. Hinclley, Vice President, American Broadeasting Company, Eric A. Johnston, President of the Motion Picture Association of America, Allen B. Kline, President of the American Farm Bureau Federation, Herbert H. Lehman, former Governor of New York, Arion Everett Lyon, Executive Secretary of the Railway Labor Executives Association, George Houk Mlead, Chairman of the Board, The Mfead Corp., Dayton, Ohio, George Meany, Secretary-Treasurer of the Ameriean Federation of Labor, and James C. Patton, President of the National Farmers Union. The Board holds its meetings on the fourth Wednesday of each month at the ECA offices in Washington D. C.
}

165. Id. $\$ 107(\mathrm{a})$. 
Board's advice ${ }^{166}$ after discussing all aspects of this controversial issue with the Board.

The Administrator is also authorized to appoint such other advisory committees as he may determine "to be necessary or desirable to effectuate the purposes" of the Economic Cooperation Act of 1948. ${ }^{107}$ During the first year of ECA, the Administrator had appointed five advisory committees under this section of the Act. One of these was the ECA Industrial Advisory Committee on dismantling plants in Western Germany appointed in August of $1948^{163}$ to advise the Administrator in connection with the section of the Act which directed the Administrator to obtain the agreement of those countries concerned that capital equipment, scheduled for removal as reparations from the three western zones of Germany, be retained in Germany if such retention will most effectively serve the purposes of the European Recovery Program. ${ }^{169}$

Another committee appointed by the Administrator under this section was the Advisory Committee on Fiscal and Monetary Problems, ${ }^{170}$ and a third advisory group was a Price Policy Committee, composed of individuals with considerable experience in business and economics and governmental price control operations, to subject ECA . price policies to careful scrutiny. ${ }^{171}$

The Anglo-American Council on Productivity has been appointed to advise the Administrator on methods of increasing industrial production. ${ }^{172}$ And the Administrator has appointed an advisory committee for the ECA China Aid Program. ${ }^{173}$

166. ECA Press Release No. 331, Dec. 22, 1948. See note 196 infra.

167. Foreign Assistance Act $\$ 107$ (b).

168. See note 114 supra for members of this committee.

169. Foreign Assistance Act $\S 115(\mathrm{f})$. See p. 893 supra for discussion of the reparations section.

170. This committee was appointed in May, 1948, and its members are: George $L$. Harrison, Chairman of the Board of the New York Life Insurance Co., Allan Sproul, President of the Federal Reserve Bank of New York, Edward Eagle Brown, Chairman of the Board, First National Bank of Chicago, W. Randolph Burgess, Chairman of the Executive Committee, National City Bank of New York, J. E. Crane, Director of Standard Oil Co. of N.J., Joseph M. Dodge, President of the Detroit Bank and also President of the American Bankers' Association, Walter W. Stewart, Chairman of the Board of the Rockefeller Foundation, and John H. Williams, Professor of Political Economy, Harvard University and Economic Adviser to the Federal Reserve Bank of New York.

171. The Price Policy Committee was appointed in November, 1948 and consists of: James F. Brownlee, Jeffrey Baker, Henry Hart, Richard Heflebower.

172. The Anglo-American Council on Productivity consists of: Philip D. Reed, Chairman of the Board of the General Electric Co., Ernest R. Breech, Executive Vice President of the Ford Motor Co., Ira Mosher, former President of NAM, J. Spencer Love, President of the Burlington Mills Corp., Victor G. Reuther, Director of Education of the United Automobile Workers, Harvey W. Brown, International President of the International Ass'n of Machinists, Lee Minton, President, Glass Bottle Blowers' Ass'n and Thomas J. Harkins, Assistant Chief Engineer of The Brotherhood of Locomotive Engineers.

173. The Public Advisory Committee for the ECA China Aid Program consists of: 


\section{Procurement Procedures Utilizing Prizate Channels of Trade}

In procuring the commodities required under the three aid acts preceding the 1948 Act, the chief emphasis was on procurement through government agencies and departments, though some commodities were procured through private channels of trade. ${ }^{174} \mathrm{~A}$ procurement keynote of the Foreign Assistance Act of 1948 is found in the section which permits the Administrator "to facilitate and maximize the use of private channels of trade. . . ." 175

ECA Regulation No. $1^{176 \cdot e s t a b l i s h e s ~ t h e ~ p r o c e d u r e s ~ t o ~ b e ~ f o l l o w e d ~}$ by the participating countries and their suppliers in obtaining reimbursement for commodities and services furnished under the program. ${ }^{17}$ It is a regulation of much importance, establishing as it does the procedures whereby billions of dollars in commodities and services for the various countries are authorized and paid for. The regulation is divided into four subparts: (a) Authorization Procedure, (b) Responsibilities of Importers and Suppliers, (c) Reimbursement for Assistance, and (d) Price Provisions.

As requests are presented by the participating countries for the procurement of commodities, they are checked against the country programs. If they are included therein, procurement authorizations are issued by ECA in Washington. These procurement Authorizations name the commodity, the amount which may be purchased, and the country of source. There are five ways in which an ECA transaction may be financed: (1) Reimbursement; (2) Letter of Commitment to a banking institution; (3) Letter of Commitment to a supplier; (4) Draft on ECA; and (5) ECA transfer of funds to a government procuring agency. ${ }^{173} \mathrm{~A}$ commonly used procedure to date has been issuance by ECA of a Letter of Commitment to a bank in the United States designated by the participating country, assuring the bank

Isaiah Bowman, President Emeritus of Johns Hopkins Univ., Arthur B. Foye, President, Far East-America Council of Commerce and Industry, Elizabeth L. Aloore, former Chairman of the USO Council, Paul V. McNutt, President and Chairman of the Board of United Service to China, and Walter S. Robertson, former Alinister Counselor for Economic Affairs at United States Embassy in Chungking.

174. Greek-Turkish Assistance Act $\$$ 1(4), 2(a)(b); Relief Recolution $\$ 2(c)$; Interim Aid Act $\$ 4$, which authorized the President to promulgate regulations controlling the purchase or procurement of commodities; in the latter Act this duty was delegated to the Secretary of State by Exec. Order No. 9914, 12 FED. Rec. \&867 (1947).

175. Foreign Assistance Act $\$ 111$ (b).

176. ECA Reg. No. 1, as amended May 3, 1949, 14 FEd. Reg. 2166 (1949).

177. See Comptroller's Opinion No. B-\$2368, Jan. 13, 1949, that "the issuance of a procurement authorization properly should be considered in all cases as constituting an obligation of appropriated funds." See also Second Edition of Brochure entitled Arresicar: Business and Europear Recovery, published by the ECA, Aug. 11, 1948, which sets forth information for those doing business under the Miarshall Plan.

178. ECA Reg. No. 1, \$201.14. 
that it will be reimbursed by ECA for payments made for the account of the approved applicant.

The purchasing for the participating countries authorized by the issuance of Procurement Authorization may be done by a government purchasing mission located in this country or by individuals through the usual private channels of trade. Once the commodities have been contracted for, the recipient country, as the approved applicant or its consignee, authorizes the bank named in the Letter of Commitment to issue Letters of Credit in favor of the supplier and upon presentation by the supplier of the customary commercial documentation such as invoice, and shipped bill of lading, plus a Supplier's Certificate, payment is made against the Letter of Credit. ${ }^{179}$

A variation of the Letter of Commitment to a bank is the Letter of Commitment to a supplier under which payments are made directly to the supplier by ECA upon submission by the supplier of the required documentation. This method of financing is used primarily to finance purchases of industrial equipment, where progress payments are customarily made.

A third method of financing is that of reimbursement to the participating country for its dollars expended in consummating an ECAapproved transaction. This method has been used extensively by the United Kingdom.

A corollary of the reimbursement system was the establishment by ECA in January, 1949 of a revolving fund account for the participating country on the books of the Treasury Department. The country is permitted to draw drafts on the ECA against such account to make payment to the supplier, who must endorse that he has complied with all significant provisions of the supplier's certificate normally required for ECA transactions, and the participating country must furnish all documentation ordinarily required for reimbursement within three months after drawing the draft. This method, of course, conserves the dollar position of the participating country permitting them the use of ECA dollars at the time of payment to the supplier.

A fifth method involves the advance of funds by ECA to another United States Government department or agency when procurement is authorized from that source; the documentation for such a transaction is customarily the same as that obtained by the procuring agency for non-ECA procurement and is retained by them for accounting to the General Accounting Office.

ECA Regulation No. 1 will be a focal point for all those who do business with ECA, and it is required reading for those who wish to fully understand the manner in which ECA makes payment for the assistance furnished the participating countries. In order to provide

179. Id. $\$ 201.19$, for standard documentation required for reimbursement. 
guidance in its use, the Administrator has published an interpretation of Regulation No. $1 .{ }^{150}$

Mr. Hoffman has made every effort to utilize to the full private procurement and private channels of trade and in his testimony before the Senate Foreign Relations Committee emphasized that:

"The ECA does not act as a purchasing or procurement agency. The ECA's activities in the field of procurement are confined to the review and approval of programs and to the financing of transactions. This fact is still not fully understood.

"The ECA was directed to encourage maximum use of private channels of trade and this we have tried to do. Our procedures for authorizing the procurement of commodities with ECA funds have aimed at two objectives; on the one hand, to give sufficient latitude for normal purchasing in commercial channels; on the other, to serve as a basis for an effective postaudit to eliminate transactions that should not be financed. The ECA issues procurement authorizations covering commodities and services to be purchased for each calendar quarter well in advance of that quarter, and permits foreign governments to issue subauthorizations to their own importers. Under these subauthorizations, private businessmen abroad can make purchases in the usual way from businessmen in the United States. The ECA procedures are thus designed to encourage trade to follow the normal pattern. As a result, as of December 31, 1948, less than one-sixth of the procurement authorized by ECA has been by United States Government agencies. The great bulk has been effected through private channels between importers abroad and American suppliers. At the same time, under our postaudit system, we have a guaranty from every participating government that it will pay back to us funds used in a way which we would not approve." 181

The "small business" amendments contained in both House and Senate bills to amend the Economic Cooperation Act caused Mir. Hoffman to reiterate with special emphasis that ECA had been acting as a financing rather than a procurement agency, and that the passage of the Patman small business amendment would be a tragic mistake. 192

The House version of the small business amendment required that the Administrator "prescribe such regulations with respect to, and impose such conditions on, procurement in the United States under this title as will secure to 'small business' in the United States, especially

180. ECA Reg. No. 1, Interpretation No. 1, 14 FED. REG. $\$ 55$ (1949); Correction to Interpretation No. 1, 14 FED. REG. 918 (1949). See also Comptroller's Opinion, No. B-82081, Jan. 12, 1949 and Feb. 14, 1949, commenting on Interpretation No. 1 suspro, as it was proposed.

181. SEN. Rep. No. 100, 81st Cong., 1st Sess. 19 (1949).

182. See the Administrator's letter to Chairman Kee of the House Committce on Foreign Affairs, as set forth in H.R. Rep. No. 440, Slst Cong., 1st Sess. 10, 11 (1949). 
the producers, a fair and substantial share of the production and business resulting from any such procurement." The amendment then defined a business as small, "if (1) its position in the trade or industry of which it is a part is not dominant, (2) number of employees does not exceed $500,(3)$ it is independently owned and operated." 183

The Senate amendment required the Administrator to appoint a "Special Assistant in charge of small business liaison." 184 The compromise clause, adopted by the Conference Committee, "[s]eeks to safeguard the interests of small business without employing language that would force the Administrator to convert the Economic Cooperation Administration into a procurement agency, to resort to the techniques of state trading, and to abandon the principle of private channels of trade as a fundamental of the act." 185

The small business amendment, as incorporated in the Economic Cooperation Act, ${ }^{186}$ is in two parts, the first of which directs that the Administrator shall assist American small business to participate equitably in the furnishing of commodities and services by making available to prospective purchasers in the participating countries information as to commodities and services produced by small independent enterprises in the United States. The second paragraph requires the Administrator to appoint a special assistant to advise and assist him in carrying out the provisions of the first paragraph and further provides that each of the quarterly reports transmitted to Congress shall include a report of all the activities under this subsection.

It is to be hoped that throughout the entire recovery program Congress will note that ECA has operated primarily as a financing and not as a procuring agency, recalling the statement of the managers on the part of the House in Conference that the new language should not lead small business to false expectations that the Administrator can or will direct a large volume of business to small business enterprises. ${ }^{187}$

To further facilitate the procurement of commodities, Congress

183. 95 Cong. Rec. 4410 (1949).

184. "Section [112] of such act [the Economic Cooperation Act] is amended by adding at the end thereof a new subsection, as follows: '(g) There shall be in the Administration a special Assistant to the Administrator. It shall be the duty of such special assistant to formulate methods to assist American small business in securing equitable participation, insofar as practicable, in the furnishing of commodities and services for the procurement with funds appropriated pursuant to this act. Such special assistant shall receive his instructions from the Administrator and shall report to the Administrator quarterly on the performance of the duties assigned to him'." 95 Cong. REc. 4069 (1949).

185. H.R. Rep. No. 440, 81st Cong., 1st Sess. 10 (1949).

186. 1949 Amendments to the Economic Cooperation Act $\$ 7(d)$, amending $\S 112$ of that Act.

187. H.R. REP. No. 440, 81st Cong., 1st Sess. 11 (1949). 
deemed it expedient to include a section in the Act to provide that when the President determined it to be in furtherance of the purposes of the Act the functions could be performed without regard to the provisions of law regulating the making, performance, amendment, or modification of contracts and the expenditure of government funds. ${ }^{1: 3}$

A few days after the passage of the Foreign Assistance Act of 1948, an Executive Order was issued which exempted the Administrator from complying with certain laws affecting the letting of government contracts and from shipping goods procured by government loans in United States flag vessels. ${ }^{\text {1s } 9}$

\section{Transportation}

Transportation of aid cargoes had not presented a major problem in the first three aid acts, but as the magnitude of foreign assistance undertaken in the European Recovery Program increased, so the problems implicit in the ocean transportation of aid cargoes increased proportionately. ${ }^{190}$ It was originally proposed in the Economic Cooperation Act that 200 vessels could be sold and 300 vessels could be chartered to participating countries for the duration of the Recovery Program. ${ }^{191}$ The Senate Foreign Relations Committee recommended the charter of 300 dry-cargo vessels to participating countries ${ }^{102}$ but

18. Foreign Assistance Act $\$ 119$.

189. Exec. Order No. 9943, 13 FED. REg. 1975 (1948). The order stated in part that the performance of the functions authorized under titles I and IV of the [Foreign Assistance] Act without regard to certain Federal Laws would further the purposes of said titles I and IV. The following United States Code titles and sections were then listed: 48 SrsT. 500, 15 U.S.C.A. $\$ 616$ (Shipment in United States Flag Vessels of Goods Financed by United States loans); Rev. Stat. \$3648, 31 U.S.C.A. \$529 (Prohibition Against Advancing Public Monies) ; Rev. Stat. \$3709, 41 U.S.C.A. $\$ 5$ (Requirement of Advertising for Bids and Procedure for Opening Bids); REv. STAT. $\$ 3709$, 41 U.S.C.A. $\$ 10$ (a) (American Materials Required for Public Use); REv. STAT. $\$ 3735,41$ U.S.C.A. $\$ 13$ (Contracts for Stationery and Supplies Limited to One Year); and 49 SrAr. 2015, 46 U.S.C.A. $\$ 1241$ (Officers and Employees of Government Required to Travel in American Ships).

190. To date most ECA transportation matters have involved the carriage of goods by sea but as amended the Economic Cooperation Act permits the Administrator to malie a limited number of vessels available to Italy for emigration under certain conditions. 1949 Amendments to the Economic Cooperation Act $\$ 10$ (c), amending $\$ 117$ of that Act.

191. "In the bill originally proposed transfer of merchant ships certified as surplus by" the Miaritime Commission vas to be permitted on Presidential order. In addition, chartering of merchant ships to participating countries to permit them to sail under foreign flags and thus avoid the higher costs of operation under American standards and the necessity of payment of the crew in dollars, was to be authorized." H.R. REr. No. 1585, E0th Cong., 2nd Sess. 35 (1948).

192. S. 2202, 80th Cong., 2nd Sess. $\$ 11$ (a) (4) (1948).

"The committee decided that, in the circumstances, it would be unwise to authorize the transfer of title to American merchant ships. On the other hand, the committee felt that to prohibit the temporary transfer for a limited period of time would be uneconomic and contrary to the best interests of the American people. The legislation therefore au- 
this provision was eliminated on the floor of the Senate, and in lieu thereof the 50 per cent clause was substituted. ${ }^{193}$

Subsequently, the House Committee rewrote into the bill the provision for chartering, cutting the number to 200 dry-cargo ships and eliminated the, 50 per cent clause suggested by the Senate. However, the Foreign Affairs Committee's recommendation to permit the chartering of these ships was jettisoned in the House, and the conference committee adopted the 50 per cent clause, ${ }^{194}$ which was incorporated in the Economic Cooperation Act.

This section provides that at least 50 per cent of ECA financed cargoes procured within the United States shall be shipped on United States flag vessels, so far as practicable, and to the extent such vessels are available at market rates. ${ }^{195}$ During the first year of the ECA program, charter rates on United States flag vessels for the movement of bulk cargoes such as coal and grain were higher than those on foreign flag vessels. In the early stages of the recovery program this differential only amounted to approximately two dollars a ton, and since there was need for all available vessels to move cargoes to Europe, the Administrator did not believe it feasible to shift cargoes from United States flag vessels to lower charter rate foreign vessels. In the first place, lower cost vessels were not available in sufficient quantity to handle the entire movement of ECA cargoes; secondly, cargo movement away from United States vessels would probably have resulted in a rise in the foreign flag rates. Consequently the Administrator deemed it advisable to maintain the 50 per cent ratio in spite of the somewhat higher cost of shipment in American bottoms.

However, in the fall of 1948 bulk shipment of ECA cargoes, particularly coal, began to decrease substantially, and it appeared that bulk cargo carriers would be available for the necessary movement in more than sufficient quantities. As a result, the differential between United States and foreign flag rates broadened considerably and foreign vessels became available at $\$ 4.50$ per ton and more below United States flag rates. Under these circumstances the Administrator believed that it would soon become impossible for him to consider that United States flag vessels were "available at market rates." Furthermore, the increasing spread between United States and foreign flag

thorizes the charter of 300 dry-cargo merchant vessels." SEN. REP. No. 935, 80th Cong, 2ind Sess. 36 (1948).

193. "This charter provision was eliminated in the Senate and in lieu thereof was substituted a provision specifying that 50 per cent of cargoes originating in the United States and related to the program should be carried in American ships if such should be available at market rates." H.R. REP. No. 1585, 80th Cong., 2nd Sess. 35 (1948).

194. S. 2202, 80th Cong., 2nd Sess. $\$ 111(2)(2)(1948)$. Economic Cooperation Act $\S 111(\mathrm{a})(2)$.

195. SEN. Rep. No. 13, 81st Cong., 1st Sess. 9 (1949). 
rates caused a direct drain on funds appropriated to ECA for European Recovery.

Accordingly, on December 3, 1948 the Administrator wrote to the Joint Congressional Committee on Foreign Economic Cooperation pointing out these circumstances and stating that as of January 1, 1949, he would no longer require the carriage of 50 per cent of bulk cargoes on United States flag vessels. ${ }^{105}$ The Administrator's announcement was misunderstood in many quarters and evoked a storm of protest. It was erroneously alleged that Mr. Hoffman had decided to abandon completely the use of United States flag vessels and provide for shipment of ECA financed cargoes exclusively in foreign bottoms. The point was simply that ECA did not propose to force half the ECA cargoes into United States flag vessels if other vessels were available to move that cargo at substantially lower rates. It was clear that a considerable number of American flag ressels should be used and would continue to be required for the movement of ECA cargoes, but the Administrator did not feel that he was required by law or justified by policy in holding to a rigid percentage at the expense of the underlying objectives of the European Recovery Program. . $^{197}$

In reporting the bill to amend the Economic Cooperation Act of 1948 to the Senate, the Foreign Relations Committee added to the controversial words "at market rates" the phrase "for United States flag vessels." ${ }^{193}$ The House Foreign Affairs Committee recommended

196. See ECA Press Release No. 331, Dec. 22, 1948, for Mrr. Hoffman's first announcement to hold in abeyance his decision of Dec. 3,1948 . This announcement points out that as a result of the French coal strike and other circumstances the demand for bull: cargo vessels has continued at a high level, and during the same period rate differentials have decreased.

197. See ECA Press Release No. 371, Jan. 18, 1949, stating that, owing to the precent need for American flag vessels to transport coal to France, there would be no problem involved in having 50\% of ECA cargoes carried by such ships until Apr. 1, 1949. This release was made just after Mr. Hoffman met with representatives of the shipping industry, the maritime unions of the $C I O$ and $A F$ of $L$, and representatives of Congress for a discussion of the $50 \%$ clause.

198. S. 1209 , S1st Cong., 1st Sess. $\$ 5$ (1949). H. R. 374S, S1st Cong., 1st Sess. $\$ 6(\mathrm{a})(\mathrm{b})(1949)$.

"The proper interpretation of the words 'at market rates' has been the subject of much dispute. The Administrator has taken the position that this meant 'world marlset rates.' Others have claimed that this meant 'United States-flag vessel market rates.' The difference in interpretation is important because, in the case of bulk-cargo ressels, the rates for United States-flag vessels are often substantially higher than those of flag vessels of other countries.

"The Administrator has testified that he regards the provisions of this scetion as burdensome and has requested that this phrase be clarified. The committee, therefore, adopted an amendment to this section by changing the phrase, 'at market rates' to 'at marlict rates for United States-flag vessels.' This will require the Administrator, in carrying out the 
the addition of the phrase "for United States flag vessels, not to exceed a reasonable differential above current world market rates." 199

While these amendments to the Economic Cooperation Act were being debated in the Senate the ECA and the American merchant marine interests agreed on a shipping section which provided that "the Administrator shall, in providing for the procurement of commodities under authority of this title, take such steps as may be necessary to assure, as far as is practicable, that at least 50 per centum of the gross tonnage of commodities procured out of funds made available under this title and transported to or from the United States on ocean vessels, computed separately for dry bulk carriers, dry cargo liner and tanker services, is so transported on United States flag vessels to the extent such vessels are available at market rates for United States flag vessels." ${ }^{200}$ This section further provides that "in the administration of this provision, the Administrator shall, insofar as practicable and consistent with the purposes of this title, endeavor to secure a fair and reasonable participation by United States flag vessels in cargoes by geographic area." 201

A corollary controversy centering about marine matters has arisen from the Administrator's policy on the payment of insurance costs of ECA cargoes with ECA dollars. In the early months of the program reimbursement was made to cover dollar costs of insurance, but in September, 1948, the Administrator announced that ECA would not supply dollars to pay insurance premiums. This was based upon the view that the size of the ECA program made it possible to operate on the basis of self-insurance and that the expenditure of ECA dollars for insurance premiums was not an economical use of funds. After carefully considering all aspects of the problem, the Administrator

provisions of this section, to make use of United States-flag vessels if they are available, even though at higher rates." SEN. REP. No. 100, 81st Cong., 1st Sess. 8 (1949).

199. H. R. 3748, 81st Cong., 1st Sess. \$ 6(a) (1949).

"The most important premise in the committee's viewpoint on the question of shipping policy in this program is that to go beyond the general concept of requiring equal sharing: of cargoes between United States and foreign shipping would result in serious prejudicing: of the recovery capabilities of the participating nations which depend substantially on shipping service as a means of earning foreign exchange." H. R. REP. No. 323, 81st Cong., 1st Sess. 25 (1949).

200. 1949 Amendments to the Economic Cooperation Act $\S 6(a)$, amending $\S 111$ (a) (2) of that Act.

201. Ibid. In conference the managers on the part of the Senate receded on a provision in the Senate version affecting shipping which forbade the use of funds authorized under the Act for charter hire, freight or passenger charges, or for any other purpose relcvant to transportation in vessels documented under the laws of a foreign country which is not a participating country and of which the owner of the vessel is not a national, on the grounds that such a provision pertained to the maritime policy of the United States rather than bearing directly upon policies involved in the European recovery program. S. 1200, 81st Cong., 1st Sess. §15. H. R. REP. No. 440, 81st Cong., 1st Sess. (1949). 
announced his decision in February, 1949 to permit ECA dollars to be used to pay for marine insurance in the same way as for other goods and services. ${ }^{202}$

The Administrator further stated that he would not require insuring with American companies as this would "single out American insurance interests from other American suppliers of goods and services and place them in a preferred class." 203

However, Senator McCarran was not fullyr satisfied with the Administrator's position with regard to United States underwriters of marine insurance and introduced an amendment on the floor of the Senate during the debates on the bill to amend the Economic Cooperation Act which provided in part that: "The Administrator shall, in providing assistance in the procurement of commodities in the United States, make available United States dollars for marine insurance on such commodities where such insurance is placed on a competitive basis in accordance with normal trade practices prevailing prior to the outbreak of World War II." The amendment also contained a requirement that if any participating country prevented United States companies from competing for marine insurance on commodities procured in the United States with ECA funds, the Administrator should require that the marine insurance on such commodities should be written with companies authorized to do a marine insurance business in the United States. ${ }^{201}$

Though the amendment passed the Senate by a vote of 59 to 22 , the Conference Committee eliminated the second provision on the grounds that it would be a mistake to require foreign governments to insure their own cargoes, and that it might constitute an interference with foreign exchange restrictions of the various countries. The first provision to make dollars available was endorsed by the Conference Committee and is now a part of the Economic Cooperation Act. ${ }^{.35}$

202. ECA Press Release No. 436, Feb. 28, 1949.

203. ECA Press Release No. 448, Mar. 9, 1949, setting forth text of a letter from the Administrator to Senator MicCarran.

204. See statement of Senator 11cCarran, 95 Coxc. Rec. 4225 (1949): "Today the marine insurance industry of America is being put at a decided disadvantage as against marine insurance companies in France, England, and other countries abroad. All the amendment would do-and it seems to me in fairness and in justice it should be adoptedis to see to it that the American marine insurance industry shall have a chance to bid for business in their line of industry."

205. 1949 Amendments to Economic Cooperation Act $\$ 7(d)$ becoming $\$ 112(j)$ of such Act. "It was the view of the managers on the part of the House that it would be a mistake to compel marine insurance on cargoes owned by foreign governments. It was believed also that to impede foreign governments from applying insofar as related to marine insurance, the exchange restrictions necessary to their compliance vith their obligations under the European recovery program would be contradictory to the tenor of the act." H. R. REP. No. 440, 81st Cong., 1st Sess. 12 (1949). 


\section{Guaranties of Investments of United States Citizens in} Participating Countries

At the time the European Recovery Program was under Congres" sional consideration, it was deemed desirable to encourage the investment of United States dollar capital in the participating countries. ${ }^{200}$ The uncertainty of conversion of foreign currency into dollars had been an important factor in deterring new dollar investments in European countries after World War II, and it was felt by Congress that a guaranty of convertibility of foreign currency realized from those investments might increase the amount of dollars invested in the participating countries. ${ }^{207}$

The guarantying of convertibility of local currency into dollars of guarantied investments of United States citizens in participating countries with the approval of the participating country and the Administrator was an entirely new concept of Foreign Assistance, and much careful consideration, both in government and out, has been devoted to this unique provision of the Act. It provided, in effect, a contract of insurance to the United States investor that for a fee of not exceeding one per cent per annum he could transfer local currency realized from a guarantied investment into United States dollars. ${ }^{204}$ As of April 1, 1949, about $\$ 962,814$ invested in informational media had been issued guaranties and $\$ 2,625,000$ had been guarantied to industry. 209

The total amount authorized for the guaranty program was $\$ 300$,000,000 and of this amount $\$ 15,000,000$ was authorized for informational media, but this latter amount was later reduced to $\$ 10,000,000$ by the appropriation bill. ${ }^{210}$ The Export-Import Bank of Washington

206. "The magnitude of recovery abroad necessitates the use of public credit. However, one of the principal aims of the European recovery program is the restablishment of private investment in productive enterprise. Since the war, chaotic economic conditiong throughout Europe and Asia have prevented this, however, it is anticipated that as recovery gathers impetus important enterprise will once more become the primary force behind the progressive development and expansion of trade abroad." H. R. REP. No. 1585, 80th Cong., 2d Sess. 38 (1948).

207. "There is evidence of a desire on the part of business to expand abroad. This is limited, however, by the inability to transfer foreign currency into dollars." H. R. REP. No. 1585, 80th Cong., 2d Sess. 38 (1948).

208. Foreign Assistance Act $\$ 111$ : "The Administrator may ... furnish assistanco to any participating country by providing for the performance of any of the functions set forth in paragraphs (1) through (5) ..." Sec. 3 states, "by making ... guaranties to any person of investments in connection with projects approved by the Administrator and the participating country concerned as furthering the purposes of this title . . " See ECA Reg. No. 4, 13 FED. REG. 3889-90 (1948), for procedure for making application for guaranties.

209. See also Sen. Rep. No. 13, 81st Cong., 1st Sess. 8, 96 (1949) ; ECA Press Release No. 337, Dec. 28, 1948.

210. Foreign Aid Appropriation Act of 1949: ". . . guaranties of investments in en- 
has acted as agent for the Administrator in issuing the guaranties for industry, and until December, 1948 acted as agent for the Administrator in issuing guaranties for informational media."11 During the first year of the recovery program, approximately two per cent of the total amount available for guaranties had been committed, the chief deterrents being lack of interest on the part of United States investors, and the reluctance of the countries to approve the investments as long as the monies set aside to cover the contract of guaranty might be subtracted from the amounts allocated to carry out their annual programs.

After carefully considering all aspects of the guaranty provision of the Economic Cooperation Act, the Senate Foreign Relations Committee concluded that:

“. . . [I]nsofar as the ECA countries were concerned, broadening the terms of the guaranties would not result in substantial amounts of increased investments unless the guaranty was made so broad that, in fact, this Government would assume most of the risks which private capital should be expected to carry.

"The proposal to earmark a certain part of the ECA appropriation for the sole purpose of making guaranties would, in the opinion of the committee, jeopardize the program. If private investors did not come forward promptly with projects of the right type at the right time, the effect would be that the segregated funds, which are urgently needed in the coming year, would be used ineffectively or would be immobilized and not be used at all." 212

The House Foreign Affairs Committee took a position 180 degrees from that recommended by the Senate Committee, it being their view that the guaranty fund should be segregated, so that whether or not the investments of United States citizens are approved would not affect the amount received by the participating country in grant or loan. The House Committee felt that after a participating country had given careful consideration to estimating and forecasting its requirements under the annual program, and an amount has been allotted them in the program, the country concerned might not wish to have the amount available under the program diminished by guaranties to United States investors. ${ }^{213}$

terprises producing or distributing informational media . . shall not exceed $\$ 10,000,000$ in the first year."

211. Amendment No. 1 to ECA Reg. No. 4, 13 Fed. Rec. 5459 (1948); Amendment No. 2 to ECA Reg. No. 4, 13 FED. REg. 8260 (1948).

212. SEN. Rep. No. 100, S1st Cong., 1st Sess. 9, 10 (1949).

213. H. R. 3734, S1st Cong., 1st Sess. § 6(c) (1) (1949):

"In addition to the amount of notes above authorized, the Administrator is authorized, for the purpose of carrying out the provisions of paragraph (3) of subsection (b) of this section, to issue notes from time to time for purchase by the Secretary of the Treasury in an amount not exceeding in the aggregate $\$ 300,000,000$ less any amount allocated privr to 
The House Committee also recommended a provision to increase the scope of the guaranty to insure against loss due to "(a) seizure, confiscation, or expropriation, (b) destruction by riot, revolution, or war, (c) any law, ordinance, regulation, decree, or administrative action (other than measures affecting the conversion of currency), which in the opinion of the Administrator prevents the further transaction of the business for which the guaranty was issued." 214

The Conference Committee rejected the House version for increasing the scope of the guaranties and limited them to a convertibility of currency, but broadened the guaranty provision to cover earnings as well as the original investment. ${ }^{215}$ Moreover the amount available for guaranties was limited to $\$ 150,000,000$ instead of $\$ 300,000,000$ as provided in the House version. ${ }^{216}$

April 3, 1949, for such purpose, until all liabilities arising under guarantees made pursuant to this authorization have expired or have been discharged."

H. R. REP. No. 323, 81st Cong., 1st Sess. 20-2 (1949):

"The new authorization is for $\$ 300,000,000$ minus such sum. It is entirely distinct from the authorizations for loans and grants. The Committee believed it to be of extremo importance to have a segregated fund available only for the financing of guarantics. T'o attempt to finance grants and guaranties from the same funds would, for obvious reasons, inhibit the use of the guaranties."

Mr. Norman Littell of the District of Columbia Bar chaired the Foreign Economic Cooperation subcommittee of the International Law Section of the American Bar Association whose report recommended segregating the guaranty fund and increasing the scopo of the guaranties section.

214. H. R. 3748, 81st Cong., 1st Sess. $\$ 6$ (b) (5) (1949).

“... [T]he guaranty to any person shall be limited to assuring the following: (1) the transfer into United States dollars of other currencies, or credits in such currencies received by such person as earnings or profits from the approved investment, as repayment or return thereof, in whole or in part, or as compensation for the sale or disposition of all or any part thereof; and (2) compensation in United States dollars for loss of all or any part of the approved investment, which shall be found by the Administrator to have becn lost to such person by reason of one or more of the following causes: (a) scizure, confiscrition, or expropriation, (b) destruction by riot, revolution, or war, (c) any law, ordinance, regulation, decree, or administrative action (other than measures affecting the conversion of currency), which in the opinion of the Administrator prevents the further transaction of the business for which the guaranty was issued. When any payment is made to any person pursuant to a guaranty as hereinbefore described, the currency, credits or assets on account of which such payment is made shall become the property of the United States Government, and the United States Government shall be subrogated to any right, title, claim, or cause of action existing in connection therewith."

H. R. REP. No. 323, 81st Cong., 1st Sess. 20-1 (1949) :

"After extensive study the Committee came to the conclusion that broadening the scope of the guaranties was the key to more significant use of them in this program. . . . The Committee believes that a broadened guaranty program must be undertaken forthwith to tap the resources of American business for helping the European Recovery Program."

215. 1949 Amendments to Economic Cooperation Act $\S 6($ b) (4), amending $\S 111$ (b) (3) of that Act. For Conference Committee comments see H. R. REP. No. 440, 81st Cong., 1st Sess. 8,9 (1949).

216. 1949 Amendments to Economic Cooperation Act $\$ 6(b)(6)$, amending $\S 111$ (b) (3) of that Act. 
In concluding its comment on guaranties the Conference Committee indicated that the attraction of American private enterprise more fully and directly into solving the economic problems of Europe must properly and adequately be dealt with in future legislation. ${ }^{217}$

\section{The Acquisition of Strategic Materials}

The opportunity to acquire strategic materials in return for Foreign Aid was considered by the Senate Foreign Relations Committee in the fall of 1947 when the Interim Aid Act was being discussed. However, lack of time before the Interim Aid Bill was to go into effect and the appreciation that the subject required careful study, led the Committee to defer action until a long-range recovery program was under consideration. ${ }^{218}$

The Harriman, Krug and Herter Committees had devoted much attention to the problem of acquiring strategic materials in return for assistance, and the intensive study contemplated became reality during the hearings on the 1948 Assistance Act before the House Foreign Affairs and Senate Foreign Relations Committees and during the debates in Congress.

Ultimately, the 1948 Assistance Act contained two sections which set forth in detail the manner in which Congress expected the strategic materials to be acquired. Two of these sections came under the section on Bilateral and Multilateral Undertakings, one providing that in each agreement, where applicable, the participating country should make appropriate provision for:

". . . facilitating the transfer to the United States by sale, exchange, barter, or otherwise for stock-piling or other purposes, for such period of time as may be agreed to and upon reasonable terms and in reasonable quantities, of materials which are required by the United States as a result of deficiencies or potential deficiencies in its own resources, and which may be available in such participating country after due regard for reasonable requirements for domestic use and commercial export of such country."

The second section provides that the participating countries would agree to negotiate (a) a future schedule of minimum availabilities, (b)

217. "The policy that will attract American private enterprise more fully and directly into the great task of solving the economic problems of Europe remains a task that must properly and adequately be dealt with in future legisiation." H. R. REP. No. 440, 31st Cong., 1st Sess. 9 (1949).

218. The Senate committee stated: "The Committee felt strongly that this entire question should be subject to intensive study whenever a long-range recovery program is under consideration by the Congress. The emergency nature of the present bill, however, makes it impractical to consider the matter in connection with interim aid." Seri. REP. No. 771, SOth Cong., 1st Sess. 13 (1947).

219. Foreign Assistance Act $\$ 115$ (b) (5). 
suitable protection for the right of access for U. S. citizens as was accorded by the participating countries to their own nationals, and (c) an agreed schedule of increased production, a percentage of which was to be transferred to the U. S. ${ }^{220}$

A third section, 117(a), came under the heading of other duties of the Administrator, and stated that in furtherance of the purposes of section $115(\mathrm{~b})(5)$, and in agreement with a participating country, the Administrator should, whenever practicable, promote, by means of funds made available for the purposes of this title, an increase in the production in such participating country. ${ }^{221}$

An "Access to Materials" Article in the Bilateral Agreements with the United Kingdom, Sweden, France, Greece, Italy, French Zone, and the Netherlands, sets forth section 115(b)(5) and (9) almost verbatim in paragraphs one and two and a third paragraph, to the effect that the participating country will undertake to make available materials originating outside their country. In the bilateral agreements with Norway, Belgium, Denmark, Iceland, and Ireland, the second paragraph states that the country will, when so requested, carry out the provisions of section $115(\mathrm{~b})(9) .{ }^{222}$ No such article was included in the agreement with Austria and Trieste.

Agreements for the acquisition of strategic materials have been entered into with the United Kingdom for the purchase of 26,000 tons of rubber, with the Netherlands for the purchase of 12,000 tons of sisal and with Belgium for certain quantities of diamonds. Moreover, the Administration has initiated several projects for increased production of strategic materials which include arrangements for a larger output of manganese in North Africa, lead in French Morocco, lcyanite

220. Id. $\$ 115(\mathrm{~b})(9)$.

221. Letter of the Comptroller General to the Administrator of Nov. 1, 1948, B-80131, states in part: "You state in your letter that said section [117(a)] is interpreted by your Administration as authorizing (1) the grant or loan of funds made available under the act directly to foreign or domestic persons, firms, or corporations for the purpose of increasing the production in participating countries of strategic materials, and (2) the purchase and transfer to such persons, firms, or corporations of equipment and property of any kind or character whatsoever which may be necessary or incident to increasing such production. In other words, section 117 (a) appears to be interpreted by your Administration as permitting the transfer of funds made available under the act to any private firm or person whatsoever, either as a loan or as an outright gift, in any amount whatever, and without any corresponding liability on the part of the participating country or countries involved. Such a broad interpretation of the section does not appear to have been suggested in the hearings on the European recovery program, nor does it find support in the legislativo history of the various bills dealing with foreign aid. Furthermore, this construction of the section appears to overlook that part thereof which provides that the Administrator shall promote an increased production of strategic materials 'in agreement with' the participating country involved."

222. First Report to Congress of the Econonic Cooperation Administration, SurPIEMENT (1948). 
in Kenya and flake graphite in Madagascar. Payments for these purchases of strategic materials are made from the local currency counterpart funds to which credits are made when commodities are furnished to the participating countries on a grant basis. ${ }^{223}$

The amendments to the Economic Cooperation Act relating to strategic materials contain three provisions, the first of which emphasizes the Administrator's obligation to utilize his bargaining power to increase the production of materials within the participating countries and their dependencies and to assist other agencies of the Government in purchasing materials. The second provision authorizes the Administrator, with the approval of the Bureau of Federal Supply, to enter into contracts for periods up to twenty years for the purchase of materials, and the third provision makes it clear that this authority does not in any way restrict the other agencies of the United States Government from stimulating production or purchasing material in other parts of the world. ${ }^{224}$

\section{Encouragement of Foreign Traiel}

Not until the Foreign Assistance Act of 1948 was under consideration had Europe sufficiently recovered from the convulsions of war so that the encouragement of travel could be considered an expeditious way of pouring badly needed United States dollars into circulation within foreign countries. ${ }^{225}$ Recognizing this important source of dollar income, Congress directed that the Administrator, in cooperation with the Secretary of Commerce, should facilitate and encourage, through private and public travel, transport and other agencies, the promotion and development of travel by citizens of the United States to and within participating countries. ${ }^{225}$

223. Foreign Assistance Act $\$ 115$ (b) (6), which states that the local currency accounts may be used for other purposes consistent with the purposes of the Act. Title $I$ of the Foreign Aid Appropriation Act of 1949 states: “. . . not less than five per centum of each special local currency account established pursuant to $\$ 115(b)(6)$ of the Economic Cooperation Act of 1948 shall be allocated to the use of the United States government for expenditure for strategic materials where available or for other local currency rcquirements of the United States of America." See 1949 Amendments to the Economic Cooperation Act $\$ 9$ (d), becoming $\$ 115$ (h) of that Act.

224. 1949 Amendments to the Economic Cooperation Act $\$ 9$ (d), becoming $\$ 115$ (i) of that Act. S. 1209, S1st Cong., 1st Sess. $\$ 9(b)$ (1949). For Senate Foreign Relations Committee views, see SEN. KEP. No. 100, 81st Cong., 1st Sess. 15 (1949). Similar provisions are incorporated in $H . R .3748$, S1st Cong., 1st Sess. $\$ 9(b)(1)(2)$ (3) (1949). For House Foreign Affairs Committee views on the Strategic Materials provisions, see H. R. REp. No. 323, 81st Cong., 1st Sess. 29, 30 (1949).

225. Travel has become the United Kingdom's largest single source of dollar earnings. Econontc Cooperation Adninistration, A Refort ort Recorery Progress nid Untred States Am, 172 (1949).

226. Foreign Assistance Act $\$ 117(\mathrm{~b})$. 
To ensure that each participating country would cooperate in facilitating and encouraging the travel of United States citizens, an article on Travel Arrangements was incorporated in the agreements signed with each of the participating countries. ${ }^{227}$ In carrying out this travel section, the Administrator has called upon the Travel Branch of the Department of Commerce's Office of International Trade, and one of the first and most encouraging steps was the elimination by ten participating countries of the visa requirements for United States citizens. ${ }^{228}$ This action was unilateral, though in each case the United States has followed with an elimination of the visa fee for travel in the United States of nationals of those countries.

A European Travel Commission, ${ }^{229}$ a sixteen-nation travel advisory body to the OEEC, has undertaken to study the flow of United States travel to Europe and estimates that during the four years, 1948-1952, between two and two and one-half billion dollars will be earned by the European travel industry. Also working to stimulate this influx of United States tourist dollars is the Travel Development Section of the Office of the Special Representative in Paris, which cooperates closely with the European travel commission and with the Inland Transport and Maritime Committees of the OEEC. ${ }^{230}$

227. The paragraph on travel in these agreements with all the participating countries is standard and reads as follows:

"The Government of - will cooperate with the Government of the United States of America in facilitating and encouraging the promotion and development of travel by citizens of the United States of America to and within participating countrics." Finst Report to Congress of te Economic Cooperation Administration, Supplement (1948).

228. Countries eliminating the visa requirement to date have been Norway, Sweden, Denmark, the Netherlands, Belgium, Luxembourg, Switzerland, Italy, Great Britain, and France.

229. This Travel Commission was constituted in Oslo in June, 1948, and in July, 1948 was recognized by OEEC as its advisory body on travel development under the recovery program.

230. The Secretary of Commerce announced in October, 1948 the appointment of a Travel Advisory Committee under the Chairmanship of Dr. H. A. Wilkinson, Chicf of Travel Branch, Office of International Trade. The members are Fraser A. Bailcy, President, National Federation of American Shipping, J. F. Brennan, Passenger Traffic Manager, United States Lines, Earl A. Emerson, President, Armco International Corp., John C. Leslie, Vice President, Pan-American World Airways, Franklin Moore, President, Inter-American Hotel Ass'n, Harry M. Paulson, President, American Soc'y of Travel Agents, L. Welch Pogue, President, Committee for World Travel, Inc., Virgil D. Recd, Associate Director of Research, J. Walter Thompson Co., Walter C. Rundle, Vice President, American Express Co., Royal W. Ryan, Executive Vice President, New York Convention and Visitors Bureau, Russell E. Singer, Executive Vice President, American Automobile Ass'n, John Russell Young, Jr., Director of International Affairs, Air Transport 'Ass'n of America. 


\section{Joint Congressional Committee}

Congress deemed it expedient to establish a Joint Congressional Committee to conduct a continuing study of United States foreign assistance programs and to review the progress achieved in the conception and execution thereof. ${ }^{231}$

The House Committee on Foreign Affairs was at the outset unsympathetic to the establishment of this Joint Congressional Committee on Foreign Economic Cooperation, believing that it encroached on the functions of their committee. ${ }^{232}$ However, in conference the House receded from its position, and the section as revised provided for ten members equally divided between the two Houses of Congress instead of the fourteen members originally proposed. Three members from each House were to be from the committee having legislative jurisdiction and two members from each House were to be from the committee having jurisdiction with respect to appropriations. ${ }^{233}$

In its report to Congress on January 10,1949, the Committee criticized the Administrator for lending money to impecunious countries, for failure to acquire strategic materials, and for his position on the shipping clause. Despite these specific criticisms, the Committee stated that it wished "to set down its belief that the workings of the Act during the last nine months have contributed much to the economic rehabilitation and political stability of Western Europe." 234

\section{Conclusion}

What judgment can be formed as to the success of the foreign assistance legislation of 1947-48? The House Foreign Affairs Committee has furnished a succinct and unequivocal answer: the European Recovery Program is working. ${ }^{235}$ The relatively few changes wrought in the Economic Cooperation Act of 1948, after Congress had carefully considered one year's operation, is good evidence that the legislation under which foreign assistance is presently being furnished and the manner in which it is being administered are worthy of the objectives to be achieved.

231. Foreign Assistance Act $\$ 124$.

232. H. R. REP. No. 1585, s0th Cong., 2d Sess. 42 (1948). The House amendment to S. 2202 provided that the United States Special Representative in Europe should lseep the Chairman of the Senate Foreign Relations Committee and House Foreign Affairs Committee and the Appropriations Committees of both Houses currently informed on his activities. H. R. REP. No. 1655, S0th Cong., 2d Sess. 33 (1948).

233. Nembers of the committee for the SOth Congress were Senators Tom Connally, Styles Bridges, H. Alexander Smith, Pat MIcCarran and Walter F. George; Representatives John M1. Vorys, James S. Fulton, Sol Bloom, John Taber and Clarenee Cannon.

Members for the S1st Congress are Senators Tom Connally, Styles Bridges, H. Alexander Smith, Pat MIcCarran and Walter F. George; Representatives John MI. Vorys, John Kee, James P. Richards, John Taber and Clarence Cannon.

234. SEN. Rep. No. 13, 81st Cong., 1st Sess. 1 (1949).

235. H. R. REP. No. 323, 81st Cong., 1st Sess. 10 (1949). 
Criteria for evaluating the success of the European Recovery Program have been crystallized by the House Foreign Aftairs Committee into two questions: Has the program fulfilled its hopes up to now? Does the rate of headway justify a further investment in the future of Europe? ${ }^{236}$

In reaching an affirmative answer to both questions the Committee noted the increase of production; financial, monetary, and economic stabilization; and expansion of trade.

As to the first point-increase of production-the committee stated that "the conclusion is justified that the expectations of the program were confirmed by Europe's production record in the first year" and cited figures to the effect that the total output of factories and mines in the participating countries during the calendar year 1948 was 14 per cent above 1947 and about equal to prewar. ${ }^{237}$

Regarding financial, monetary and economic stabilization, the Committee found that testimony had demonstrated that the participating countries with few exceptions have made real progress toward attaining internal financial stability, and emphasized the important role played by the counterpart funds in fighting inflation and in achieving financial stability. ${ }^{238}$

The Senate Foreign Relations Committee, after full consideration of the extension of the European Recovery Program, has also submitted a favorable report to the Senate:

"The program is now successfully under way. With the momentum gained during the past 12 months, this second and critical year should bring the participating countries still closer to the achievement of those great ideals of common welfare and peace embodied in the recovery program." ${ }_{233}$

The reasons for extending Foreign Assistance remain ever strong. The congressional committees charged with the responsibility of foreign affairs and policy have emphasized that a program well begun must be well completed if the Economic Cooperation Act is to remain an effective instrument in reestablishing sound economic conditions in Et1rope. ${ }^{240}$

236. Id., at 4 .

237. The Committee further states:

"Excluding Western Germany, steel output is currently at a rate exceeding the prewar high of 1937 and 25 percent above that of 1947. The coal shortage has eased; although tonnage in the Bizone and the United Kingdom remained below that of prewar, production in all other important coal fields in Western Europe increased almost to prewar levels." Id. at 5. See also Sev. Rep. No. 100, 81st Cong., 1st Sess. 3 (1949).

238. H. R. Rep. No. 323, 81st Cong., 1st Sess. 6, 7 (1949).

239. SEN. REP. No. 100, 81st Cong., 1st Sess. 21 (1949).

240. Id. at 21. See also H.R. Rep. No. 323, 81st Cong., 1st Sess, 3 (1949). 


\title{
THE YALE LAW JOURNAL

\begin{tabular}{lll}
\hline Voldure 58 & MAY, 1949 & Nunges 6 \\
\hline
\end{tabular}

\section{EDITORIAL BOARD}

Frank M. Wozencraft

Editor-ist-Chicf

\author{
Girvan Pect \\ Excoutize Editor
}

HERBERT L. PACKER

Johar D. Calmoun

Cosmment Editor

Geoses M. Treistzas
Note Editor

Article Editor

\section{ROBERT H. LounseURy \\ Case Editor}

Leo P. Arnaboldt, Jr. EDWARD N. BeNJARITN

Hugo L. Black, JR. RICHARd M. FitzSEmarons

Wirliaxr D. Ginn

WIILIA3I E. HEGARTY

JANTES D. HILEORN

ARTOLD HOFFMAN

RICHARD F. IGL
Gerald D. Katcher Wirliasr F. Krinsch, Je. John E. Loosrts

Domald I. Afedlock

Arteur M. Mirchaelson

E. Gabriel Perie Jerodse Preston, Jo.

Norasais Redich

Whitaney N. Seyaroug, JR
Dotglas W. Fraticuot

Mansoging Editor

Mrewr: G. Suresas

Mo:troe S. Sricers

Do:iald F. TuRites

Euryort E. Vose

A:RDEEW MI. WCOD

Cenares A. Wrugre

LLEWELLY: P. Young

Ravso::D H. You::

Engar A. Zrgigrast

MIARIE MICALamon, Business Secrelory

Subscription price $\$ 5.00$ per year

This number, $\$ 1.00$

Canadian subscription price $\$ 5.50$ per ycar; Forcign, $\$ 5.75$ per ycar;

for prices osz other isstes intuire

Yale Law Journal Company, Intc., Box 401 A Yale Station, New Hazen, Conssctiest

\section{CONTRIBUTORS TO THIS ISSUE}

BorIs I. BITTKER: B.A. 1938, Cornell University; LL.B. 1941, Yale University. Law Clerk to Judge Jerome N. Frank, 1941-42; Office of the General Counsel, Lend-Lease Administration, 1942-43; Chief, Liquidation Section, Office of the Alien Property Custodian, 1945-46. Associate Professor of Law, Yale Law School.

Davtd MI. CRAwford. B.A. 1938, Cornell University; LL.B. 1941, Yale University. Member of the New York Bar. Formerly visiting Iecturer in Law; Yale Law School. Office of the General Counsel, Economic Cooperation Administration. 